Revista lus et Praxis, Año 16, N², 2010, pp. 273 - 330

ISSN 0717 - 2877

Universidad de Talca - Facultad de Ciencias Jurídicas y Sociales

"La criminalidad organizada. Una aproximación al derecho penal italiano, en particular la responsabilidad de las personas jurídicas y la confiscación"

Raúl Carnevali Rodríguez

\title{
LA CRIMINALIDAD ORGANIZADA. UNA APROXIMACIÓN AL DERECHO PENAL ITALIANO, EN PARTICULAR LA RESPONSABILIDAD DE LAS PERSONAS JURÍDICAS Y LA CONFISCACIÓN*
}

\author{
ORGANIZED CRIME. AN APPROACH TO THE ITALIAN \\ CRIMINAL LAW WITH PARTICULAR REFERENCE TO LIABILITY \\ OF LEGAL PERSONS AND CONFISCATION
}

Raúl Carnevali Rodríguez**

\begin{abstract}
RESUMEN
El crimen organizado es una de las manifestaciones criminales que se han fortalecido dentro de la economía globalizada. Italia, por su experiencia con la mafia, ha desarrollado diversos mecanismos, entre ellos, la responsabilidad del ente y la confiscación, que son medidas dirigidas a prevenir el lucro ilícito, que es lo que motiva a estas organizaciones.

ABSTRACT

Organized crime is a criminal manifestations that have been strengthened within the global economy. Italy for its experience with the mafia, has developed various mechanisms, including the liability of legal persons and the confiscation, which are measures aimed at preventing illicit profit, which is what motivates these organizations.

\section{PalabRas ClaVE}

Criminalidad Organizada, Responsabilidad de las Personas Jurídicas, Confiscación

KEY WORDS

Organized Crime, Liability of Legal Persons, Confiscation
\end{abstract}

\footnotetext{
* Este trabajo se realizó durante una estancia de investigación del autor postdoctoral en el Departamento de Derecho Penal "Cesare Beccaria" de la Universidad de Milán. Ésta fue financiada por Becas Chile y por el Centro de Estudios de Derecho Penal de la Universidad de Talca. El autor agradece los comentarios y sugerencias formuladas por el Dr. Francesco Viganò (Universidad de Milán). Trabajo recibido el 15 de julio y aprobado el 1 de octubre de 2010.

** Doctor en Derecho; Profesor Asociado de Derecho Penal y Director del Centro de Estudios de Derecho Penal, Universidad de Talca. Correo electrónico: rcarnevali@utalca.cl.
} 


\section{INTRODUCCIÓN}

La primera dificultad que se presenta al tratar este tema es delimitar el objeto de análisis. En efecto, no resulta fácil precisar qué se entiende por criminalidad organizada'. Justamente, una de sus particularidades es su capacidad para adaptarse a las nuevas realidades sociales, "descubriendo" dónde están sus grietas que permitan actuar. En el pasado, grupos más o menos organizados actuaban en aquellas zonas rurales en donde el Estado estaba presente sólo formalmente. Así sucedió en los orígenes de la mafia siciliana.

La expresión mafia se empleó por primera vez en 1865 en la relación del prefecto de Palermo Filippo Gualtiero al Ministro del Interior para referirse a una asociación delictiva ${ }^{2}$. En todo caso, en sus orígenes no puede afirmarse sin más que la mafia era una asociación criminal, pues de algún modo se vincula con las particularidades sociales propias de la isla de Sicilia: era una sociedad de orden feudal, donde el poderoso asumía el deber de proteger al débil, y éste hallaba en aquél protección y cuidado. Precisamente estas características fueron aprovechadas por el Estado italiano que se estaba formando, convirtiendo a la mafia en una especie de poder intermedio entre el Estado y la sociedad. En ese momento comenzó a relacionarse con el poder político ${ }^{3}$. Estas estructuras feudales vinculadas con la tierra, muy propia de la vieja mafia, empiezan a cambiar a fines del siglo XIX y comienzos del XX con la inmigración siciliana a los Estados Unidos ${ }^{4}$ Y es que las posibilidades económicas que ofrecía el país americano eran enormes. Además, el inmigrante siciliano no sólo no perdía su vínculo con su antiguo terruño, sino que además trasladaba sus costumbres, en cuanto a buscar protección con el poderoso, el don. De esta manera, se formaron nuevas asociaciones mafiosas en los Estados Unidos, las que siguieron relacionadas con Sicilia. Si bien el fascismo propinó duros golpes a la mafia con el trabajo de Cesare Mori, Ilamado el "prefecto de acero",

\footnotetext{
${ }^{1}$ Ya lo planteaba, FiandaCA, Giovanni, "Criminalità organizzata", L'Indice penale, 1991, pp. 5 y ss.; cfr. además, Dı MARTINO, Alberto, "Criminalita organizzata e reato transnazionale, diritto penale nazionale: I'attuazione in Italia della cd. Convenzione di Palermo", Diritto penale e processo 1, 2007, pp. 11 y ss.; INSOlERA, Gaetano, Diritto penale e criminalità organizzata, II Mulino, Boloña, 1996, p. 37; ZafFARONI, Eugenio, "Il crimine organizzato: una categoria fallita", en Moccla, Sergio (Edit.), Criminalità organizzata e risposte ordinamentali, Edizioni Scientifiche Italiane, Nápoles, 1999, pp. 76 y ss.; RoxıN, Claus, "Problemas de autoría y participación en la criminalidad organizada", Traducción de Anarte, Enrique, Revista Penal 2, 1998, p. 65. Sosteniendo la artificialidad del discurso, Pavarini, Massimo, "Lo sguardo artificiale sul crimine organizzato", en Gıostra, Glauco; Insolera, Gaetano (Edits.), Lotta alla criminalità organizzata: gli strumenti normativi, Giuffrè, Milán, 1995, pp. 75 y ss.

${ }^{2}$ Romano, Salvatore, Storia della mafia, Mondadori, Verona, 1966, p. 139. Sobre la historia de la mafia siciliana, cfr. también BLock, Antón, The Mafia of a Sicilian Village 1860-1960, Basil Blackwell, Oxford, 1974, passim. Sobre el desarrollo histórico de la camorra napolitana, Dı FIORE, Gigi, La camorra e le sue storie, Utet, Turín, 2005, passim. Rovıтo, Pier Luigi, "Mentalità emergenziale e crimine organizzato: profili storici", en MoccıA, Sergio (Edit.). Criminalità organizzata e risposte ordinamentali, Edizioni Scientifiche Italiane, Nápoles, 1999, pp. 11 y ss., quien expone las manifestaciones que tienen lugar en Italia ya en el siglo XVI.
}

${ }^{3}$ Romano, Storia, cit. nota n. 2, pp. 158 y ss.

${ }^{4}$ Romano, Storia, cit. nota n. 2, pp. 231, 263 y ss. 
se pudo recomponer y reorganizar a finales de la Segunda Guerra Mundial. En efecto, con el objeto de facilitar el desembarco de las tropas en Sicilia y combatir a los nazis y fascistas, los agentes norteamericanos se contactaron con la mafia americana de origen siciliano -en particular con Lucky Luciano-, quienes facilitaron sus relaciones en la isla. Luego, los aliados americanos ubicaron en cargos políticos de ciudades sicilianas a personas relacionadas con la mafia ${ }^{5}$.

Hoy el mundo globalizado ofrece infinitas oportunidades a la criminalidad organizada, pues las mayores facilidades tecnológicas dificultan enormemente su persecución ${ }^{6}$. Precisamente, la participación en un mundo económico "abierto" a través de empresas aparentemente legales facilita el encubrimiento de sus actividades ilícitas ${ }^{7}$.

La criminalidad organizada es quizás la manifestación más evidente de la nueva criminalidad propia de la globalización. Con ello no se quiere decir que antes no existían crímenes asociados a organizaciones -basta tener presente el delito de asociación ilícita- sino más bien, que los nuevos tiempos favorecen su conformación.

Una de las particularidades de las sociedades modernas es la incidencia que ha tenido la globalización. Hoy ya no se discute que la trascendencia de este fenómeno no se limita a la esfera económica, pues también se puede apreciar en el campo de las comunicaciones gracias a los avances tecnológicos. En este sentido, los Estados han restringido sus limitaciones comerciales, dando lugar a una ampliación de los mercados. Precisamente, en la consecución de este propósito se han impulsado a escala global una serie de políticas dirigidas a facilitar la libre circulación de determinados factores productivos, como son, por ejemplo, los capitales, las mercancías, las personas y los servicios. En efecto, la mayor libertad y, por ende, los menores controles estatales para la circulación de estos factores, brinda enormes espacios de actuación a un tipo de crimina$\operatorname{lidad}^{8}$. Por lo anterior, en un contexto de esta naturaleza dicha delincuencia es eminentemente económica. Lo que no impide, claro está, que puedan verse afectados otros bienes jurídicos, como sucede, por ejemplo, con el tráfico de

\footnotetext{
${ }^{5}$ Romano, Storia, cit. nota n. 2, pp. 297 y ss.

${ }^{6}$ Patalano, Vincenzo, "Profili problematici della corruzione internazionale", en Patalano, Vincenzo (Edit.), Nuove strategie per la lotta al crimine organizzato transnazionale, Giappichelli, Turín, 2003, pp. 391 y ss.; ZúNIIGA Rodríguez, Laura, Criminalidad organizada y sistema de derecho penal. Contribución a la determinación del injusto penal de organización criminal, Comares, Granada, 2009, pp. 61 y ss.

${ }^{7}$ Así lo destaca, BARATTA, Alessandro, "Mafia: rapporti tra modelli criminologici e scelte di politica criminale", en Moccia, Sergio (Edit.), Criminalità organizzata e risposte ordinamentali, Edizioni Scientifiche Italiane, Nápoles, 1999, pp. 104-105.

${ }^{8}$ LaUdati, Antonio, "Criminalità organizzata e riciclaggio", en Patalano, Vincenzo (Edit.), Nuove strategie per la lotta al crimine organizzato transnazionale, Giappichelli, Turín, 2003, p. 219.
} 
personas, de estupefacientes, de armas. No obstante, en estos casos lo que motiva en buena medida a la delincuencia organizada es el lucro ${ }^{9}$.

En todo caso cabe advertir que también se puede estar frente a una criminalidad organizada que persiga fines diversos a los económicos, como sucede con algunas manifestaciones terroristas: el grupo se estructura y persigue fines ideológicos, políticos o incluso religiosos. Sin perjuicio de ello y consciente de su gravedad, mi atención se dirigirá a la de carácter económico, que también tiene una importante incidencia en la vida económica y política de los Estados.

Debe tenerse presente que los fenómenos económicos y sociales que tienen lugar por el proceso globalizador han permitido el surgimiento de nuevas formas de criminalidad, que se caracterizan por su organización, en algunos casos por su transnacionalidad y, particularmente, por su gran poder económico. Es en este ámbito, donde debe situarse la Ilamada criminalidad organizada, cuyas particularidades recién citadas exigen prestarle especial atención. En efecto, que sea organizada, pone de manifiesto que se trata de estructuras con algún grado de jerarquización, que dificultan una investigación criminal, pues en no pocos casos se presentan problemas para determinar la atribución de responsabilidad penal, dada la separación espacio-temporal entre la decisión de los jerarcas y la ejecución del delito ${ }^{10}$. A ello debe sumarse su gran capacidad económica, que les permite, incluso, desestabilizar las instituciones políticas de un Estado a través de la corrupción de sus funcionarios ${ }^{11}$.

Por otro lado, su carácter transnacional obstaculiza de manera significativa su persecución, pues se requiere el esfuerzo conjunto de la comunidad internacional, por medio de políticas homogéneas y de cooperación judicial ${ }^{12}$. Actividades delictivas, como el tráfico de armas, de drogas o de personas conforman un claro ejemplo de su perfil internacional. Dada esta particularidad es que la Convención de las Naciones Unidas contra la delincuencia organizada transnacional, conocida como Convención de Palermo, se dirige a definir instrumentos que permitan conformar una estrategia común entre los Estados ${ }^{13}$.

\footnotetext{
${ }^{9}$ Silva SÁnchez, Jesús María, La expansión del Derecho penal. Aspectos de política criminal en las sociedades postindustriales, $2^{a}$ Edición, Civitas, Madrid, 2001, p. 83.

${ }^{10}$ Así lo deja claro, SILvA, La expansión, cit. nota n. 9, p. 87.

${ }^{11}$ Para un examen amplio de la corrupción y sus consecuencias, CAFERRA, Vito Marino, Il sistema della corruzione. Le ragioni, i soggetti, i luoghi, Laterza, Roma-Bari, 1992; PATAlano, "Profili problematici", cit. nota n. 6, pp. 391 y ss.

${ }_{12}$ PISANI, Mario, "Criminalità organizzata e cooperazione internazionale", Rivista italiana di diritto e procedura penale, 1998, pp. 703 y ss.

${ }^{13}$ Ver Convención En: http://www.acnur.org/biblioteca/pdf/1292.pdf [visitado el 4/06/2010]. Cfr. Rosl, Elisabetta (Edit.), Criminalità organizzata transnazionale e sistema penale italiano, Ipsoa, Milán, 2007, passim; cfr. además, Nunzı, Alfredo, "La Convenzione delle Nazioni Unite contro la criminalità organiz-
} 
Justamente, dicha Convención, en su Art. 2, entiende por grupo delictivo organizado: "grupo estructurado de tres o más personas que exista durante cierto tiempo y que actúe concertadamente con el propósito de cometer uno o más delitos graves o delitos tipificados con arreglo a la presente Convención con miras a obtener, directa o indirectamente, un beneficio económico u otro beneficio de orden material".

Tales particularidades las distinguen de otras manifestaciones criminales, como pueden ser los delitos cometidos por una pluralidad de sujetos. Y es que su especial organización puede erosionar gravemente las instituciones del Estado, poniendo en serio riesgo la estabilidad democrática ${ }^{14}$. En efecto, tales formas de criminalidad no tienen pretensiones políticas, ni buscan alcanzar el poder estatal. Por el contrario, su eficacia radica en actuar en la sombra, como una fuerza omnipresente tras el poder establecido. Para ello emprenden acciones dirigidas a corromper a determinados funcionarios. Probablemente, aquí radica uno de los mayores peligros de la criminalidad organizada, pues deslegitima a las instituciones estatales ante los ciudadanos, generando percepciones de inseguridad pública, quebrantando con ello las bases de un Estado de Derecho. Lamentablemente, varios países latinoamericanos se ven afectados por la criminalidad organizada, debido en parte, a sus debilidades institucionales. Por tal motivo se torna urgente adoptar medidas para fortalecer las estructuras democráticas y sus medios de control, como una herramienta eficaz, amén de las punitivas, para combatir esta clase de organizaciones criminales.

A este respecto, debe tenerse presente que dado su nivel organizacional, participa muchas veces dentro de la economía lícita, valiéndose de sus instrumentos. Basta citar en el caso del tráfico de drogas las actividades de lavado de dinero ${ }^{15}$. De manera que buena parte de su éxito se debe a su intromisión dentro del aparato estatal, ya sea por funcionarios corruptos o, simplemente, por la ausencia de elementos de control eficaces.

zata transnazionale", en BASSIOUNI, Cherif M. (Edit.), La cooperazione internazionale per la prevenzione e la repressione della criminalitá organizata e del terrorismo, Giuffrè, Milán, 2005, pp. 213 y ss.; MıLITELLO, Vincenzo, "Le strategie di contrasto della criminalità organizzata transnazionale tra esigenze di politica criminale e tutela dei diritti umani", en PARANO, Carola; CEnTONZE, Alessandro (Edits.), L'attività di contrasto alla criminalità organizzata, Giuffrè, Milán, 2005, pp. 249 y ss.

${ }^{14}$ LAUDATI, "Criminalità organizzata", cit. nota n. 8, p. 217: "El crimen organizado constituye un peligro para las democracias modernas por la extraordinaria capacidad de acumular enormes riquezas y de contaminar y condicionar las instituciones".

${ }^{15}$ Castaldo, Andrea; Naddeo, Marco, Il denaro sporco. Prevenzione e repressione nella lotta al riciclaggio, Cedam, Padua, 2010, passim; FerOLA, Laura, IL riciclaggio dei proventi illeciti nel diritto internazionale, Giuffrè, Milán, 2005, pp. 19 y ss.; SCialoja, Antonio, Le nuove norme antiriciclaggio. Criminalità organizzata e riciclaggio, Maggioli editore, Santarangelo di Romagna, 2006, passim; Cordero BLANCO, Isidoro, El delito de blanqueo de capitales, 2a Edición, Aranzadi, Pamplona, 2002, passim. 
Por cierto, diversas son las actividades en las que participan organizaciones criminales organizadas, las que se ven favorecidas, como se ha señalado, por las condiciones económicas actuales producto de la globalización. Además del tráfico de drogas a que se ha hecho referencia, puede citarse el tráfico de armas, que también aumenta en aquellas regiones donde el crimen organizado impera, pues requieren controlar territorios, desplazando a otras organizaciones. Ello, sin perjuicio de constituirse en fuente de financiamiento para actividades terroristas ${ }^{16}$. También intervienen en el tráfico de personas. Entre las razones que suelen argumentarse para el crecimiento de tan execrable actividad, suele citarse la apertura de los mercados, la mayor facilidad en el transporte y el fuerte crecimiento demográfico. Esto último de manera sobresaliente en los países africanos y del sudeste asiático, unido a las mayores brechas económicas, ha generado demanda de fuerza de trabajo, la que se desarrolla en términos de explotación y de nueva esclavitud ${ }^{17}$. Por último, tampoco puede dejarse de lado la llamada cibercriminalidad, considerando el importante número de transacciones en las que se emplean nuevas tecnologías ${ }^{18}$.

\footnotetext{
${ }^{16}$ Ver Convenio Internacional de las Naciones Unidas contra el financiamiento al terrorismo, En: http:// www.cinu.org.mx/multi/ter/documentos/Cfinancsp.pdf [visitado el 5/06/2010]; BAssIOunl, Cherif M., "Strumenti giuridici peri il contrasto del terrorismo internazionale: un'analisi di carattere politico", en BASSIOUNI, Cherif M. (Edit.), La cooperazione internazionale per la prevenzione e la repressione della criminalitá organizata e del terrorismo, Giuffrè, Milán, 2005, pp. 93 y ss.; BAuccio, Luca, L'accertamento del fatto reato di terrorismo internazionale. Aspetti teorici e pratici, Giuffrè, Milán, 2005, passim; LAUDATI, "Criminalità organizzata", cit. nota n. 8, p. 217.

${ }^{17}$ Cada año ingresan clandestinamente a Europa unas 400.000 personas. Hoy son cerca de 8.000 .000 de personas los inmigrantes ilegales dentro de la Unión Europea, es decir, 1 de cada 3 inmigrantes ingresaron clandestinamente. Las mujeres que son objeto de tráfico y luego destinadas a la explotación sexual son casi 2.000.000. En relación a los niños, en Asia cerca de 1.000.000 son explotados sexualmente, y buena parte de ellos se encuentran en Tailandia, conocido paraíso del turismo sexual. Cfr. García Arán, Mercedes (Coord.), Trata de personas y explotación sexual, Comares, Granada, 2006, passim; Pérez CEPEDA, Ana Isabel, Globalización, tráfico internacional ilícito de personas y Derecho penal, Comares, Granada, 2004, passim; Tinebra, Giovanni; Centonze, Alessandro (Edits.), Il traffico internazionale di persone, Giuffrè, Milán, 2004, passim.

${ }^{18}$ Cfr. Romeo Casabona, Carlos María (Coord.), El cibercrimen: nuevos retos jurídico penales, nuevas respuestas político criminales, Comares, Granada, 2006, passim; Morales García, Óscar (Dir.), Delincuencia informática: problemas de responsabilidad, Cuadernos del Poder Judicial 9, 2002, passim; ILARDA, Giovanni; Marullo, Gianfranco (Edits.), Cybercrime: conferenza internazionale. La Convenzione del Consiglio d'Europa sulla Criminalità Informatica, Giuffrè, Milán, 2004, passim; LuPÁrIA, Luca (Edit.), Sistema penale e criminalità informatica, Giuffrè, Milán, 2009, passim; VulpiANI Domenico, "Criminalità organizzata ed informatica", en Parano, Carola; Centonze, Alessandro (Edits.), L'attività di contrasto alla criminalità organizzata, Giuffrè, Milán, 2005, pp. 187 y ss.; RESTA, Federica, "Cybercrime e cooperazione internazionale, nell'ultima legge della legislatura", Giurisprudenza di merito 9, 2008, pp. 2147 y ss.; PІсотт, Lorenzo, "La ratifica della Convenzione Cybercrime del Consiglio d'Europa", Diritto penale e processo 6, 2008, pp. 700 y ss.; HeRzoG, Felix, "Straftaten im Internet, Computerkriminalität und die Cybercrime Convention", Política Criminal No 8, D1, 2009, pp. 1 y ss. En: http:// www.politicacriminal.cl/Vol_04/n_08/Vol4N8D1.pdf [visitado el 10/06/2010]; MoltrA, Soumyo D.,
} 
El ciberespacio-espacio sin fronteras-ofrece oportunidades maravillosas para la difusión de las ideas y del conocimiento, pero también es campo fértil para la criminalidad dada su especial vulnerabilidad. Así como aumenta la calidad de vida al mismo tiempo crecen los riesgos. Las principales características: a) La red no tiene una estructura jerarquizada que permita establecer sistemas de control, lo que dificulta enormemente la verificación de la información que por allí circula; b) El creciente número de usuarios y la cada vez mayor facilidad de acceso, quienes pueden ser tanto víctimas como autores de delitos. Además, el anonimato de los llamados cibernautas facilita la comisión de delitos y las dificultades de persecución; c) La facilidad para poder acceder a la información y con ello alterar datos, así como destruir sistemas informáticos, sin que los proveedores del servicio puedan hacer algo, y d) La capacidad de generar peligros globales es manifiesta, pues es perfectamente posible el empleo de la red para la comisión de delitos terroristas. La difusión de la información de manera rápida y a bajo costo permite a las organizaciones delictivas perpetrar delitos con mayor facilidad.

\section{El discurso crítico al llamado Derecho penal de la emergencia.} ¿ES POSIBLE UN DERECHO PENAL MÍNIMO?

Por todo lo expuesto, si se pretende enfrentar la criminalidad organizada con eficiencia no puede seguir pensándose en las herramientas propias de un Derecho penal pensado para los problemas del siglo XIX. En efecto, me parece que poco puede hacer un Derecho penal construido esencialmente sobre la base del homicidio y de los delitos contra la propiedad como sus ejes centrales. En este sentido, debe reexaminarse si un Derecho de tales características puede enfrentar adecuadamente estos nuevos desafíos ${ }^{19}$. No debe olvidarse que se trata de un Derecho pensado para delitos cometidos por un autor individual, por lo general, desamparado socialmente. Dicho en términos simples, el Derecho penal que siempre hemos estudiado tiene, en términos generales, como soporte al delincuente pobre. En cambio, la delincuencia de la globalización comprende otros factores: se trata de agrupaciones, en algunos casos muy poderosas, que cometen delitos de naturaleza económica, pero que pueden repercutir en bienes de otra naturaleza y cuyas actividades pueden poner en serio riesgo la estabilidad democrática de un país, a través de la corrupción de políticos y funcionarios públicos. Asimismo, la criminalidad organizada presenta conexiones cada vez más estrechas no sólo en el ámbito puramente económico sino también político, que les permite asegurar contratos con la administración

"Developing Policies for Cybercrime", European Journal of Crime, Criminal Law and Criminal Justice Vol. 13/3, 2005, pp. 435 y ss.

${ }^{19}$ Así lo sostiene, Aleo, Salvatore, "Criminalità transnazionale e definizione della criminalità organizzata: il requisito dell'organizzazione", en Patalano, Vincenzo (Edit.), Nuove strategie per la lotta al crimine organizzato transnazionale, Giappichelli, Turín, 2003, p. 10; SıIVA, La expansión, cit. nota n 9, pp. 83 y 99. 
pública. Un ejemplo, es el caso del tratamiento de los residuos tóxicos, que genera cuantiosas ganancias -en Italia ya se habla de la Ecomafia ${ }^{20}$.

Por lo anterior, resultan discutibles las propuestas de quienes sostienen el discurso crítico al Ilamado Derecho penal de la emergencia y de la excepcionalidad. Críticas que provienen principalmente de aquellos que sostienen propuestas político-criminales cercanas al denominado derecho penal mínimo ${ }^{21}$. La realidad de nuestros tiempos parece demostrar que se trata de un problema creciente que se torna "ordinario" y, por tanto, que requiere de instrumentos que respondan eficientemente ${ }^{22}$. No puede sostenerse que toda intervención en esta área nos lleva a un Derecho penal autoritario ${ }^{23}$.

En la línea del discurso mínimo Ferrajoli se manifiesta crítico con los delitos asociativos, estimando que es suficiente para abordarlos los delitos-objeto a cuya realización se habría conformado la asociación. Al respecto, señala: "De ahí se sigue que para el derecho no deben existir delincuentes políticos sino sólo delincuentes comunes: en el doble sentido en el que ningún hecho no contemplado como delito común debe ser penalizado por razón exclusiva de su carácter 'objetivamente político' y ningún delito debe ser tratado de forma distinta que los demás por razón del carácter 'subjetivamente político' de sus motivaciones. En el primer aspecto, toda penalización a título de delito 'político' termina en la tutela excesivamente anticipada de figuras de peligro abstracto o presunto en contradicción con el principio de lesividad o, incluso, como ocurre en los delitos asociativos, en una duplicación de la responsabilidad penal ya afirmada en los delitos comunes, como la tenencia de armas, los actos de violencia consumados o intentados o el concurso en su comisión o preparación" ${ }^{\prime 24}$.

\footnotetext{
${ }^{20}$ Plantamura, Vito, "Ecomafia, reati associativi e diritto penale dell'economia", Rivista trimestrale di diritto penale dell'economia, 2007, pp. 73 y ss.; Lo Monte, Elio, "Ecomafia: il controllo penale tra simbolicità ed effettività", en Patalano, Vincenzo (Edit.), Nuove strategie per la lotta al crimine organizzato transnazionale, Giappichelli, Turín, 2003, pp. 235 y ss.

${ }^{21}$ FeRRAJOLI, Luigi, Derecho y razón. Teoría del garantismo penal, Traducción de Andrés Ibáñez, Perfecto y otros, Trotta, Madrid, 1995, pp. 807 y ss., donde trata el subsistema penal de excepción.

${ }^{22}$ Aleo, Salvatore, Sistema penale e criminalità organizzata. Le figure delittuose associative, Giuffrè, Milán, 1999, pp. 2-5.

${ }^{23}$ ZafFaronI, "Il crimine organizzato", cit. nota n. 1, pp. 84 y ss.; Moccia, Sergio, "Prospettive non 'emergenziali' di controllo dei fatti di criminalità organizzata. Aspetti dommatici e di politica criminale", en MocCiA, Sergio (Edit.), Criminalità organizzata e risposte ordinamentali, Edizioni Scientifiche Italiane, Nápoles, 1999, pp. 149 y ss.

${ }^{24}$ FerRajol, Derecho y razón, cit. nota n. 21, pp. 832-833. En p. 833: “La misma argumentación vale también, evidentemente, para las demás figuras de delitos y de delincuentes especiales, igualmente reconducibles a fenomenologías criminales globales -el bandidaje, la mafia, la camorra- y, por lo demás, ni siquiera caracterizadas por una especificidad en abstracto de los bienes jurídicos protegidos. También la expulsión del derecho penal de tales tipologías de autor responde a una garantía de seguridad contra las perversiones sustancialistas e inquisitivas, además de a una elemental exigencia de igualdad. Se trata, en efecto, de figuras informadas por el paradigma constitutivo y, por tanto,
} 
La postura de Ferrajoli parece desconocer los riesgos manifiestos que representan las organizaciones criminales, independiente de si cometen o no los delitos-objeto, pues en muchos casos su sola conformación representa un peligro que no se puede desconocer. Como señalan Marinucci y Dolcini, no son pocos los casos en que la organización ni siquiera requiere cometer delitos: ya es suficiente la intimidación que su presencia genera para lograr su propósito $^{25}$. Esperar que tales delitos se verifiquen supone, inexplicablemente, renunciar a importantes herramientas para combatir manifestaciones del la criminalidad organizada. Se otorgarían enormes espacios de libertad que contaminarían la vida económica y política de un país ${ }^{26}$.

Parece evidente que conductas como las propias de la criminalidad organizada requieren de herramientas eficaces y ello se logra sólo a través de una intervención penal oportuna, sin que sea necesario esperar a estar frente a actos de ejecución de los delitos-objeto. Afirmar lo contrario, tornaría inútil cualquier medida preventiva. Lo expuesto podría inscribirse dentro de la llamada "teoría de la anticipación". En efecto, los delitos de organización suponen que se está frente a dimensiones institucionales que favorecen la comisión de delitos dentro de su contexto. En consecuencia, las sanciones de que se disponen para actos vinculados a la organización se justificarían sobre la base de anticipar la protección de bienes jurídicos que se verían afectados por la comisión de los delitos fines de la organización ${ }^{27}$. Es decir, dado el incremento de peligrosidad

contrarias al carácter exclusivamente regulativo que deben tener las normas penales. Naturalmente, también en estos casos la naturaleza mafiosa o camorrista de un delito puede considerarse como un rasgo particularmente grave en el momento de la comprensión y la valoración equitativa del hecho. Pero ni siquiera en estos casos se justifican figuras de delito especial, como lo es típicamente, en nuestro ordenamiento, la asociación de tipo mafioso prevista por el art. 416 bis del Código Penal en lugar de la normal avocación para delinquir. También la mafia, como el terrorismo, debe y puede ser afrontada con los medios penales ordinarios".

${ }_{25}$ MarinucCl, Giorgio; Dolcinı, Emilio, "Diritto penale 'minimo' e nuove forme di criminalità", Rivista italiana di diritto e procedura penale, 1999, p. 817 (traducción al español de Raúl Carnevali en Revista de derecho penal y criminología № 9, 2002, pp. 147 y ss.). Precisamente, el art. 416 bis del Código penal italiano al tipificar el delito de asociación de tipo mafioso se comprende el aprovechamiento de su fuerza intimidatoria. Sobre esto último, SPAGnolo, Giuseppe, L'associazione di tipo mafioso, $5^{\text {a }}$ Edición, Cedam, Padua, 1997, pp. 49 y ss.; De LIGUORI, Luigi, "La struttura normativa dell'associazione di tipo mafioso", Cassazione Penale, 1988, pp. 1609 y ss.

${ }^{26}$ MARINUCCI; DolCINI, "Diritto penale", cit. nota n. 25, p. 817. La respuesta a este artículo en FerRajoli, Luigi, "Sul diritto penale minimo (risposta a Giorgio Marinucci e a Emilio Dolcini)", Foro italiano, Parte Quinta, 2000, pp. 126 y ss.

27 Así lo expone, Siıva SÁnchez, Jesús María, "La «intervención a través de organización» ¿una forma moderna de participación en el delito?", en Dolcinı, Emilio; PAliero, Carlo Enrico (Edits.), Studi in onore di Giorgio Marinucci, T. II, Giuffrè, Milán, 2006, p. 1880; cfr. además, De Vero, Giancarlo, Tutela penale dell'ordine pubblico, Giuffrè, Milán, 1988, pp. 256 y ss. 
que representa la organización, es que se justificaría adelantar la intervención punitiva $^{28}$.

Una cosa es defender principios básicos como ultima ratio-nadie discute su trascendencia-, pero ello no puede hacerse sobre la base de renunciar a priori al Derecho penal o a una mayor intensidad de éste, argumentando como lo hacen los defensores del llamado derecho penal mínimo de que toda manifestación expansiva es perniciosa y antigarantista ${ }^{29}$. No siempre será una decisión errada huir al Derecho penal, si la protección de determinados intereses individuales o colectivos así lo justifica ${ }^{30}$.

\section{CARACTERÍSTICAS ESENCIALES DE LA CRIMINALIDAD ORGANIZADA}

Precisamente, en los últimos veinte años se vienen sucediendo una serie de instrumentos normativos internacionales que ponen de manifiesto la especial preocupación que existe sobre el tema ${ }^{31}$. En la esfera de las Naciones Unidas comenzó a tratarse este tema a través del Ilamado Plan Mundial de acción de Nápoles contra la delincuencia organizada transnacional de 1994, que luego fue aprobado por la Asamblea General de las Naciones Unidas el 23 de diciembre de $1994^{32}$. Más adelante, tras una serie de reuniones y seminarios internacionales se aprobó en 2000 la Convención de Palermo, ya mencionada supra, la que contiene importantes disposiciones. En efecto, amén de la definición de grupo organizado, se dispone, entre otras medidas, la responsabilidad de las personas jurídicas -art. 10- y el decomiso o confiscación -art. 12-. Precisamente, estas dos medidas serán abordadas más adelante, pues constituyen importantes instrumentos para enfrentar la delincuencia organizada de carácter económico.

Así también, la Unión Europea ha manifestado especial atención al fenómeno que se examina. Es así que el Tratado de Ámsterdam, en el título VI sobre Disposiciones relativas a la cooperación policial y judicial en materia penal,

\footnotetext{
${ }^{28}$ En estos términos se expresa, CANCIO Melí, Manuel, "Sentido y límites de los delitos de terrorismo", en Serrano-Piedecasas, José Ramón; Demetrio Crespo, Eduardo (Dirs.), Terrorismo y Estado de Derecho, lustel, Madrid, 2010, pp. 389-390.

${ }^{29}$ Así lo cree, ZafFaronI, "Il crimine organizzato", cit. nota n. 1, pp. 85 y ss. Al respecto, Marinuccl; DolCINI, "Diritto penale", cit. nota n. 25, pp. 819-820.

${ }^{30}$ CarneVall, Raúl, "Derecho penal como ultima ratio. Hacia una política criminal racional", en Problemas de política criminal y otros estudios, LegalPublishing, Santiago, 2009, pp. 3 y ss.

${ }^{31}$ ZúNIIGA, Criminalidad organizada, cit. nota n. 6, pp. 48 y ss.; NunZı, "La convenzione", cit. nota n. 13, pp. 213 y ss.

${ }^{32}$ Ver En: http://daccess-dds-ny.un.org/doc/UNDOC/GEN/N95/769/54/PDF/N9576954.pdf?OpenElement [visitado el 12/06/2010]. Cfr. MiCHELINI, Gualtiero; PoLIMENI, Gioacchino, "Il fenomeno del crimine transnazionale e la Convenzione delle Nazione Unite contro il crimine organizzato transnazionale", en Rosı, Elisabetta (Edit.), Criminalità organizzata transnazionale e sistema penale italiano, Ipsoa, Milán, 2007, pp. 8 y ss.
} 
se hacía referencia a la criminalidad organizada y la necesidad de establecer en este contexto acciones comunes. Justamente, en este marco se sitúa la Acción Común 1998/733/JAI para la tipificación penal de la participación en una organización delictiva ${ }^{33}$. Allí también se insistía en la necesidad de que los ordenamientos nacionales regularan la responsabilidad, incluso penal de las personas jurídicas -art. 3-. Diez años después, se acuerda la Decisión Marco 2008/841/JAI sobre lucha contra la criminalidad organizada ${ }^{34}$, dispuesta para lograr una adecuada armonización de las legislaciones de los Estados miembros ${ }^{35}$. Al igual que en los instrumentos anteriores, se reitera la necesidad de disponer de medidas para responsabilizar a las personas jurídicas -arts. 5 y $6-$.

También se pueden citar, aunque relacionadas con el terrorismo, la Decisión Marco

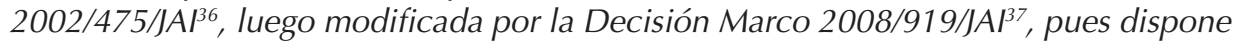
de normas relativas a organizaciones terroristas y qué se entiende por tales y sobre la responsabilidad de las personas jurídicas.

Si bien, como se ha dicho, se presentan ciertas dificultades para delimitar un concepto de criminalidad organizada, sí es posible precisar sus entornos considerando sus rasgos más característicos, algunos ya mencionados supra ${ }^{38}$. Precisamente, la determinación de sus elementos esenciales facilita la armonización de las legislaciones nacionales, que es uno de los caminos más eficaces

${ }^{33}$ Ver En: http://eur-lex.europa.eu/LexUriServ/LexUriServ.do?uri=CELEX:31998F0733:ES:HTML [visitado el 12/06/2010]. Cfr. PeCClol, Annamaria, Unione Europea e criminalità transnazionale, Giappichelli, Turín, 2005, pp. 131 y ss.; D'AMATO, Antonio, "La cooperazione internazionale nell'esercizio della funzione giurisdizionale. Dalle rogatorie alle squadre investigative comuni in attuazione dei principi del "terzo pilastro" del Tratatto sull'Unione Europea", en Patalano, Vincenzo (Edit.), Nuove strategie per la lotta al crimine organizzato transnazionale, Giappichelli, Turín, 2003, p. 119; SALAzAR, Lorenzo, "Misure di contrasto alla criminalità organizzata elaborate dall'Unione Europea", en BASSIOUNI, Cherif M. (Edit.), La cooperazione internazionale per la prevenzione e la repressione della criminalitá organizata e del terrorismo, Giuffrè, Milán, 2005, pp. 128 y ss.

${ }^{34}$ Ver En: http://eur-lex.europa.eu/LexUriServ/LexUriServ.do?uri=OJ:L:2008:300:0042:0045:ES:PDF [visitado el 12/06/2010].

${ }^{35}$ FORNASARI, Gabriele, "Le strategie di contrasto alla criminalità orgnizzata: aspetti comparatistici nell'esperienza europeo-continentale", en FornASARI, Gabriele (Edit.), Le strategie di contrasto alla criminalità orgnizzata nella prospettiva di diritto comparato, Cedam, Padua, 2002, pp. 173 y ss.

${ }^{36}$ Ver En: http://eur-lex.europa.eu/LexUriServ/LexUriServ.do?uri=OJ:L:2002:164:0003:0007:ES:PDF [visitado el 12/06/2010].

${ }^{37}$ Ver En: http://eur-lex.europa.eu/LexUriServ/LexUriServ.do?uri=OJ:L:2008:330:0021:0023:ES:PDF [visitado el 12/06/2010].

${ }^{38}$ Para conocer el desarrollo histórico del crimen organizado en diversos países europeos, FiJnaut, Cyrille; PaOl, Letizia (Edits.), Organised Crime in Europe. Concepts, Patterns and Control Policies in the European Union and Beyond, Springer, Dordrecht, 2006, pp. 21 y ss.; cfr. COHEN, A. K., "The concept od criminal organization", British Journal of Criminology. Vol. 17, 1977, pp. 97 y ss. 
para poder enfrentar la criminalidad organizada, sobre todo, tomando en cuenta que algunos casos tienen un carácter transnacional ${ }^{39}$.

Es cierto que sus presupuestos más elementales también pueden encontrarse en el delito de asociación ilícita, pero no son lo mismo y por tanto no deben confundirse. Como se ha expuesto supra, la mayor peligrosidad que representan estas clases de organizaciones justifica la determinación de particulares medidas preventivas y sancionatorias ${ }^{40}$.

Que se hable de "organizada" pone de manifiesto que se está frente a ciertas estructuras que ofrecen una disposición jerárquica de distribución de funciones, ya sea que se manifiesten en empresas "lícitas" -por ejemplo, una sociedad de importación que sirve también para el tráfico ilícito de estupefacientes- o en composiciones directamente criminales ${ }^{41}$. En este contexto, se pone de manifiesto que quienes participan en la organización persiguen fines que son comunes; es decir, toda la estructura jerárquica, la división de actividades, la distribución de las funciones apuntan a la consecución de determinados fines ilícitos, los que, atendiendo la clase de criminalidad organizada que estamos examinando, son, en definitiva, de carácter lucrativo. Ahora bien, para lograr aquello pueden, a su vez, realizarse numerosas actividades, algunas de ellas pueden ser incluso lícitas -así, conformación de empresas-, como así también otras claramente ilícitas - por ejemplo, intimidar, corromper-. Pero el objetivo final, reitero, es el lucro de carácter ilícito ${ }^{42}$. En este sentido, no cabe exigir de la organización criminal un programa determinado; por el contrario, es perfectamente posible sostener cierta indeterminación al menos parcial, pues considerando su complejidad es preferible establecer un marco más general que permita mayores espacios para la adopción de medidas preventivas. En todo

\footnotetext{
${ }^{39}$ La Europol, en el documento Enfopol 161-REV-3, ha determinado 11 supuestos para determinar que se está frente a delitos comprendidos dentro de la criminalidad organizada: a) más de dos personas; b) distribuciones de funciones; c) permanencia; d) control interno; e) sospecha de comisión de un delito grave; f) actividad internacional; g) violencia; h) uso de estructuras comerciales o de negocios; i) blanqueo de capitales; j) presión al poder público, y k) ánimo de lucro. Así lo expone, ZúÑIGA, Criminalidad organizada, cit. nota n. 6, p. 58; GutiérRez RodríGuez, Marceliano, "La delincuencia organizada", en VVAA., lurisperitorum digesta, Vol. I, Ediciones Universidad de Salamanca, Salamanca, 2000, p. 283.

${ }^{40}$ Así lo sostiene, ZúñIIGA, Criminalidad organizada, cit. nota n. 6, p. 58.

${ }^{41}$ SILVA, La expansión, cit. nota n. 9, p. 87; Ziffer, Patricia, El delito de asociación ilícita,. Ad-Hoc, Buenos Aires, 2005, pp. 67 y ss.; AleO, "Criminalità transnazionale", cit. nota n. 19, pp. 15-16.

${ }^{42}$ ZúNIIGA, Criminalidad organizada, cit. nota n. 6, p. 128; Fernández Cruz, José Ángel, "La 'empresa criminal': Los 'delitos de comercio' ilícito como factor de aparición del fenómeno del 'blanqueo de capitales'", Revista de Estudios Criminológicos y Penitenciarios 5, 2002, p. 90; SzCZARAnsky, Clara, "El Consejo de Defensa del Estado y el control de la criminalidad organizada y del lavado de dinero", en Poltioff, Sergio; Matus, Jean Pierre (Coords.), Gran criminalidad organizada y tráfico ilícito de estupefacientes, ConoSur, Santiago, 2000, pp. 48-52.
} 
caso, ello no impide al menos exigir que su estructura tenga la capacidad de cometer delitos graves ${ }^{43}$. En definitiva, la organización debe ser lo suficientemente idónea para cometer delitos, si bien no expresamente determinados, sí determinables conforme al contexto en que ésta se desarrolla ${ }^{44}$.

Asimismo, debe tratarse de una estructura organizativa que tenga un carácter permanente -lo exige también la Convención de Palermo-, a fin de evitar confusiones con otras actividades delictivas de carácter plural, como pueden ser los casos de coautoría ${ }^{45}$. Una exigencia de esta naturaleza explica el porqué estas organizaciones disponen de ciertos códigos de actuación a los que se someten sus integrantes: es la forma de asegurar su permanencia y proyección en el tiempo. No debe olvidarse que al tratarse de organizaciones delictivas, no pocos de sus integrantes conocen ciertas informaciones que no pueden ser desveladas. Por ello no es extraño que se establezcan ritos de iniciación y un fiel cumplimiento a la ley de silencio -como puede ser l'omertà, comprendida en el art. 416 bis del Código penal italiano- ${ }^{46}$.

El otro elemento a considerar es la transnacionalidad. Si bien no es un elemento esencial, sí está presente en algunas asociaciones criminales. Es por ello que las convenciones internacionales precedentemente citadas ponen de manifiesto tal característica, a fin de disponer de medidas comunes que permitan enfrentar a la criminalidad organizada con eficacia, sobre todo, teniendo en consideración la mayores facilidades que brinda una economía globalizada ${ }^{47}$.

\footnotetext{
${ }^{43}$ Expresamente lo señala la Convención de Palermo, entendiendo por delito grave: "Art. 2 b) Por "delito grave" se entenderá la conducta que constituya un delito punible con una privación de libertad máxima de al menos cuatro años o con una pena más grave".

${ }^{44}$ Cavaliere, Antonio, "Tipicità ed offesa nei reati associativi", en Patalano, Vincenzo (Edit.), Nuove strategie per la lotta al crimine organizzato transnazionale, Giappichelli, Turín, 2003, p. 86; Ateo, Salvatore, "Associazione, organizzazione, concorso esterno", en PARANo, Carola; CentonzE, Alessandro (Edits.), L'attività di contrasto alla criminalità organizzata, Giuffrè, Milán, 2005, p. 180.

${ }^{45}$ Carnevalı, Raúl; Fuentes, Hernán, "Informe jurídico sobre la eventual aplicación del delito de asociación ilícita establecido en el art. 16 de la Ley No 20.000", Política Criminal 6, D1, 2008, p. 8. En: http://www.politicacriminal.cl/n_06/d_1_6.pdf [visitado el 14/07/2010].

${ }^{46}$ Omertà es un suerte de solidaridad, interna y externa, que por una parte garantiza protección a la organización y, por otro, se traduce en una impermeabilidad de todo lo que rodea a la organización. Constituye una práctica que pone de manifiesto total incondicionalidad al grupo y a sus reglas, como asimismo rechazo al ordenamiento jurídico estatal. Cfr. De LiguorI, "La struttura normativa", cit. nota n. 25, p. 1612; BeCCHI, Ada; Rey, Guido M., L'economia criminale, Laterza, Bari, 1994, p. 62, señalan que los riesgos evidentes que comportan actividades de esta naturaleza exigen una particular fidelidad de sus miembros.

${ }^{47}$ SILvA, La expansión, cit. nota n. 9, p. 88.
} 
La Convención de Palermo establece en su art. 3 cuándo el delito se entiende transnacional:

“a) Se comete en más de un Estado; b) Se comete dentro de un solo Estado, pero una parte sustancial de su preparación, planificación, dirección o control se realiza en otro Estado; c) Se comete dentro de un solo Estado, pero entraña la participación de un grupo delictivo organizado que realiza actividades delictivas en más de un Estado, o d) Se comete en un solo Estado, pero tiene efectos sustanciales en otro Estado".

Con esta norma se pretende disponer de una base mínima que agilice la cooperación entre los Estados y con ello facilitar la persecución de los delitos que se cometan en este ámbito. Es indudable que si hoy los mercados no presentan límites, se incentiva la libre circulación de capitales, personas, mercaderías y servicios, los medios de comunicación y el ciberespacio actúan sin reconocer soberanías nacionales, entregar la persecución de la criminalidad organizada -que precisamente se ha desarrollado enormemente en este marco- a la decisión unilateral de cada Estado, no tiene sentido alguno y resulta completamente ineficaz ${ }^{48}$. Por lo demás, la transnacionalidad del Derecho penal tampoco debe extrañar. Desde hace muchos años se viene transitando por este camino, difuminando cada vez más el principio de territorialidad. Sin ir más lejos, basta apreciar el proceso de integración europea, donde ya se habla en sentido amplio de un Derecho penal de la Unión Europea ${ }^{49}$, como asimismo,

\footnotetext{
${ }^{48}$ Cfr. Rosı, Elisabetta, "Il reato transnazionale", en Criminalità organizzata transnazionale e sistema penale italiano, Ipsoa, Milano, 2007, pp. 67 y ss.; Dı MARTINO, "Criminalita organizzata", cit. nota n. 1, pp. 16 y ss.; LAUDATI, Antonio, "I delitti transnazionali. Nuovi modelli di incriminazione e di procedimento all'interno dell'Unione Europea", Diritto penale e processo 4, 2006, pp. 401 y ss.; VIGNA, Piero Luigi, "Le nuove sfide della criminalità organizzata", en BECUCCI, Stefano; MASSARI, Monica, Mafie nostre, mafie loro. Criminalità organizzata italiana e straniera nel Centro-Nord, Edizioni di Comunità, Turín, 2001, pp. 187 y ss.; Militello, Vincenzo; Paol, Letizia; Arnold, Jörg (Edits.), I/ crimine organizzato come fenomeno internazionale. Forme di manifestazione, prevenzione e repressione in Italia, Germania e Spagna, Ed. Iuscrim, Max Planck Institut, Friburgo, 2000, passim.

${ }^{49}$ Conforme al Tratado de Lisboa desaparece la distinción de los pilares. Por tanto, ya no es posible argumentar, para determinar la esfera de actuación en materia penal, entre las áreas de integración o de cooperación. En términos muy generales, el nuevo Tratado introduce todo un Capítulo relativo a la Cooperación judicial en materia penal -art. 69 A a 69 E-. En él se dispone que el Parlamento Europeo y el Consejo podrán a través de directivas adoptadas conforme procedimiento legislativo ordinario - de codecisión-, establecer normas mínimas relativas a la definición de las infracciones penales y de las sanciones en ámbitos delictivos que sean de especial gravedad y tengan una dimensión transfronteriza. Entre estos ámbitos delictivos se comprenden: el terrorismo, el tráfico ilícito de drogas, el tráfico ilícito de armas, el blanqueo de capitales, la corrupción y la delincuencia organizada. Asimismo, se contempla la creación de una Fiscalía Europea, a partir de Eurojust, para combatir las infracciones que perjudiquen a los intereses financieros de la Unión. Competencia que se puede ampliar, si el Consejo Europeo así lo determina. Cfr. SotIs, Carlo, "La novità in tema di diritto penale europeo", en BILANCIA, Paola; D'Amıco, Marilisa (Edits.), La nuova Europa dopo il Tratatto di Lisbona, Giuffrè, Milán, 2009, pp. 145 y ss.; De Francesco, Giovannangelo, "Internazionalizzazione del diritto e della politica criminale: verso un equilibrio di molteplici sistemi penali", Diritto penale e processo 1, 2003, pp. 5 y ss.
} 
el desarrollo de los principios de primacía y complementariedad en el Derecho penal internacional ${ }^{50}$.

III. Algunas medidas para enfrentar La CRIMINALIDAD ORGANIZADA, EN ESPECIAL LA RESPONSABILIDAD DE LAS PERSONAS JURÍDICAS Y LA CONFISCACIÓN. LA EXPERIENCIA ITALIANA

\section{Consideraciones preliminares}

Atendiendo que mi análisis se centra en la Ilamada criminalidad organizada de carácter económico y no en aquella que persigue fines ideológicos o políticos-aunque ciertamente pueden concurrir ambos-, es que examinaré aquellas herramientas que, precisamente, apuntan en esa dirección; esto es, qué medidas pueden ser eficaces para prevenir el lucro ilícito. Como se apuntó supra, lo que motiva a la criminalidad organizada es obtener el máximo de beneficio económico. Toda su estructura organizativa apunta hacia ello, por lo que aprovechan todos los espacios que las legislaciones nacionales pueden ofrecer. Por tanto, las medidas que se dispongan deben golpear el "brazo económico" de la organización criminal, que puede llegar a ser tan peligroso como el "brazo armado"51.

Por lo anterior analizaré dos instrumentos dispuestos en el ordenamiento italiano que tienen un claro "sentido económico", a saber, la responsabilidad de las personas jurídicas y la confiscación. Que mi mirada se dirija a la legislación italiana obedece a la perenne presencia -como en ningún otro país europeo- del crimen organizado en la vida económica y política de Italia. Por largo tiempo ha sufrido la violencia de las diversas formas de mafia. Asimismo, la sociedad italiana fue testigo, durante la década del noventa, de importantes casos de corrupción -campaña llamada "Manos limpias"-, tanto pública como privada, en las que se vieron involucradas connotadas autoridades, algunas de ellas acusadas de connivencia con la mafia. Parece importante, pues, estudiar

\footnotetext{
${ }^{50}$ El principio de primacía se ha aplicado para determinar la competencia de los llamados tribunales penales internacionales ad hoc-así, para la ex Yugoslavia y Ruanda- y el de complementariedad respecto de la Corte Penal Internacional. Cfr. EL ZEIDY, Mohamed M., "The principle of complementarity: a new machinery to implement international criminal law", Michigan Journal of International Law Vol. 23, 2001-2002, pp. 881 y ss.; BRown, Bartram, "Primacy or Complementarity: Reconciling the Jurisdiction of National Courts and International Criminal Tribunals", The Yale Journal of International Law Vol. 23, 1998, pp. 394 y ss.; StIGEN, Jo, The relationship between the International Criminal Court and National Jurisdictions. The Principle of Complementarity, Nijhoff Publishers, Leiden-Boston, 2008, pp. 74 y ss.

${ }^{51}$ Con estos términos, CORvi, Angela, "Nuove risposte al crimine organizzato tra diritto penale e sanzioni ammnistrative", en Mazza, Oliviero; Vıganò, Francesco (Edits.), Il "pachetto" sicurezza 2009, Giappichelli, Turín, 2009, p. 375.
} 
la experiencia italiana y cuáles son las medidas necesarias para enfrentar la criminalidad organizada.

Si bien es cierto, la responsabilidad de las personas jurídicas fue introducida en la legislación italiana en 2001 -Decreto Legislativo $N^{\circ} 231$-, respecto de un reducido número de delitos, con los años este elenco se ha ido ampliando. Es así, que en 2006, conforme a la Ley $\mathrm{N}^{\circ} 146$, concretamente el art. 10, se extendió la responsabilidad del ente a los delitos asociativos, entre los que se encuentra el delito de asociación de tipo mafioso del art. 416 bis del Código penal italiano, dando cumplimiento con ello a la Convención de Palermo contra el crimen organizado internacional ${ }^{52}$. Sin embargo, pronto, la doctrina se percató que la Ley № 146 de 2006 cumplía parcialmente el mandato dispuesto en la Convención de Palermo, pues sólo se hacía cargo de los delitos transnacionales, mas no de aquellos casos en que el ente estuviera vinculado a un grupo criminal "interno" 53 . Por lo anterior y a fin de evitar tal laguna legislativa, la Ley $N^{\circ} 94$ de 15 de julio de 2009 -conocida como il "pacchetto" sicurezzaintrodujo el art. 24 ter al Decreto Legislativo $N^{\circ} 231$ relativo a los delitos de criminalidad organizada. De este modo, también se dio cumplimiento a la ya citada Decisión Marco 2008/841/JAI de la Unión Europea sobre lucha contra la criminalidad organizada.

Por su parte, la confiscación ha sido muy utilizada en esta esfera, tanto como medida preventiva como sancionatoria. Entre las diversas formas de confiscación se comprende la llamada confiscación ampliada -confisca allargata-, dispuesta especialmente para luchar contra la criminalidad organizada. Ya no sólo se apunta, como es tradicional, a los bienes provenientes del delito o a aquellos de valor equivalente-otros bienes de valor similar-, sino a todos aquellos bienes respecto de los cuales se tiene serias sospechas de su origen ilícito dada la desproporción que se presenta con los ingresos; es decir, tiene lugar una incongruencia entre la posesión de estos bienes y los ingresos declarados.

\section{Otras medidas de carácter penal y extrapenal}

Además de las ya señaladas -que se abordarán infra-, también existen otras herramientas de naturaleza penal para enfrentar la criminalidad organizada. En

\footnotetext{
52 Astrologo, Annamaria, "Prime riflessioni sulla definizione di reato transnazionale nella L. № 146/2006", Cassazione Penale 4, 2007, pp. 1789 y ss.; Dı MARTINO, "Criminalita organizzata", cit. nota n. 1, pp. 11 y ss.; MARENGHI, Francesco, "La responsabilità delle persone giuridiche nel crimine organizzato transnazionale", en Rosı, Elisabetta (Edit.), Criminalità organizzata transnazionale e sistema penale italiano, Ipsoa, Milán, 2007, pp. 259 y ss.

${ }^{53}$ Así lo destacan, D'Amato, Antonio, "Art. 10 I. 16 marzo 2006, № 146", en Presuttı, Adonella; BerNASCONI, Alessandro; FIORIO, Carlo, La responsabilità degli enti. Commento articolo per articolo al D. Legisl. 8 giugno 2001 No 231, Cedam, Padua, 2008, p. 307; Corvı, "Nuove risposte", cit. nota n. 51, p. 366.
} 
este sentido, los delitos asociativos han jugado un papel preponderante, pues considerando su función de tutela anticipada, permiten sancionar la integración en la estructura organizativa de la asociación criminal, sin tener que acreditar la comisión de aquellos delitos que forman parte del programa criminal. Cabe destacar, entre los tipos específicos contemplados en el ordenamiento italiano, el art. 416 del Código penal -asociación para delinquir-; art. 416 bis del Código penal -asociación de tipo mafioso-; art. 74 del Decreto del Presidente de la República № 309 de 9 de octubre de 1990 -asociación para el tráfico ilícito de estupefacientes-; art. 270 bis del Código Penal -asociación con finalidades terroristas-. Asimismo, se ha prestado especial atención a los delitos que en esta esfera se cometen, como son los delitos de corrupción, de tráfico de personas, blanqueo de capitales, sólo por citar algunos.

En materia procesal y particularmente desde la perspectiva investigativa, se dispone de órganos dedicados exclusivamente a la persecución de esta clase de actividades. En Italia está la Dirección Nacional Antimafia y el Procurador Nacional Antimafia -art. 371 bis del Código Procesal Penal- ${ }^{54}$.

El papel de la Dirección Nacional Antimafia es la coordinación investigativa en materia de criminalidad organizada, tanto nacional como internacional. Se compone del Procurador Nacional y de veinte magistrados del Ministerio Público -en Italia no hay separación entre magistrados y Ministerio Público, forman parte del Poder Judicial.

A su vez, están las Direcciones Distritales Antimafia, veintiséis en todo el país, que son las que investigan y la Dirección investigativa antimafia que depende del Ministerio del Interior, y en la que forman parte la Policía del Estado, Carabineros y la Guardia de Finanzas, está encargada de coordinar la investigación preventiva de las actividades del crimen organizado y realizar las indagaciones propias de la policía judicial.

Todas las actividades emprendidas por estos organismos tienen como eje central: la centralización y la especialización. Es la única forma de enfrentar adecuadamente determinadas estructuras organizativas de orden criminal. Además, en el plano internacional su trabajo se coordina con otras instituciones policiales y judiciales. La dimensión transnacional a la que tanto se ha aludido, deja más que en evidencia la necesidad de una coordinación de esta naturaleza. Justamente, los instrumentos internacionales pretenden alcanzar

\footnotetext{
${ }^{54}$ Cfr. TeRESI, Renato, Direzione nazionale e Direzioni distrettuali antimafia, Giuffrè, Milán, 1993, passim; FERRAJOLI, Luigi, "Il coordinamento delle indagini nei procedimenti per delitti di criminalità organizzata", en CoRso, Piermaria; InSOleRA, Gaetano; STORTONı, Luigi (Coords.), Mafia e criminalità organizzata, T. II, Utet, Turín, 1995, pp. 429 y ss.; LAUDATI, Antonio, "Il coordinamento delle indagini nel crimine organizzato transnazionale. II ruolo della Direzione nazionale antimafia alla luce dei coordinamenti in sede europea", en Rosı, Elisabetta (Edit.), Criminalità organizzata transnazionale e sistema penale italiano, Ipsoa, Milán, 2007, pp. 373 y ss.
} 
la adecuada armonización legislativa entre las naciones, entendiendo que la existencia de "paraísos penales" o tratamientos penales diversos puede tornar ineficaz cualquier medida preventiva que se quiera adoptar. Es el caso de los llamados paraísos fiscales, en donde se ofrecen cuentas bancarias offshore -privacidad, secreto bancario, baja o nula tributación- que pueden dificultar enormemente las investigaciones acerca del origen del dinero. Lo llamativo es que en varios países europeos permiten abrir cuentas bancarias offshore-Reino Unido y Suiza, entre otros $-{ }^{55}$.

En sede procesal y penitenciaria se han dispuesto las Ilamadas medidas premiales, esto es, toda una serie de instrumentos que se aplican a quienes colaboran de manera relevante con la justicia -pentiti-56. Éstos han mostrado ser eficaces en la lucha contra las asociaciones mafiosas, tomando en cuenta el especial papel que aquí le cabe a l'omertà, o ley del silencio: una especie de reglas de solidaridad entre sus miembros, que torna impermeable a la asociación -para sus integrantes son más importantes las normas de la asociación que las del Estado-. Asimismo, estas medidas cumplieron una relevante función en el desmantelamiento de uno de los grupos terroristas más violentos que asolaron Italia durantes los setenta y ochenta, como fueron las Brigadas Rojas. Pues bien, entre las medidas se disponen: la protección a los colaboradores, la rebaja de penas, como así también excepciones a los colaboradores para que puedan disfrutar de medidas alternativas a la pena -art. 4 bis, 58 ter del ordenamiento penitenciario-.

Es cierto que medidas de esta naturaleza pueden generar riesgos desde la perspectiva de la información que se entrega, pues con el propósito de obtener beneficios ésta puede ser tergiversada. Pero ello es un riesgo inherente a toda colaboración con la justicia, la que debe ser contrastada con otros antecedentes que obren en poder del Ministerio Público o del juez en su caso. El sistema procesal cuenta con herramientas que le permiten confrontar los dichos del colaborador. Tampoco me parece razonable plantear su rechazo desde una perspectiva ética, argumentándose que se trata de una práctica deleznable en la que no puede incurrir un Estado de Derecho. Por de pronto, las legislaciones de los Estados más democráticos contemplan medidas de esta naturaleza. Es indudable que tienen un carácter eminentemente utilitarista, pues en definitiva lo que pretende es prevenir delitos de especial gravedad "premiando" a quie-

\footnotetext{
${ }^{55}$ Para conocer las diversas legislaciones, Grundi, Milton; ApARna, Nathan, Offshore Business Centres: A world Survey, 8a Edición, Sweet \& Maxwell, Londres, 2008, passim.

${ }^{56}$ BERNASCONI, Alessandro, La collaborazzione processuale. Incentivi, protezione e strumenti di garanzia a confronto con l'esperienza statunitense, Giuffrè, Milán, 1995, pp. 79 y ss.; Musco, Enzo, "Los colaboradores de la justicia entre el pentitismo y la calumnia: problemas y perspectivas", Traducción de SÁnchez, Virginia, Revista Penal 2, 1998, pp. 35 y ss.
} 
nes colaboran. Si la finalidad del Derecho penal es la prevención de delitos, debe recurrir a instrumentos que tengan un menor costo social. Es preferible que el Estado renuncie a parte de la pena u otorgue beneficios -costo- si con ello previene futuros delitos -beneficio-. Por otra parte, no debe olvidarse que puede lograrse un beneficio adicional, a saber, la reinserción de los arrepentidos o pentiti.

En cuanto a las medidas de carácter extrapenal que se han dispuesto en el ordenamiento italiano, pueden mencionarse, entre otras, las siguientes:

a) La exclusión en la participación en los contratos públicos de concesión o suministros de servicios de aquellos empresarios que no han denunciado a la autoridad judicial hechos de concusión o de extorsión cometidos a través de métodos mafiosos o para facilitar la actividad de una organización de tipo mafioso, y que por ello no ha podido participar en el concurso público de concesiones de contratos públicos -art. 38 letra m ter del Decreto Legislativo № 163 de 2006 (llamado Código de contratos públicos)-. Se aplica para aquellos casos en que el empresario con su conducta, si bien no ha cometido un delito de favorecimiento personal -art. 378 del Código penal italiano-, tampoco se halla bajo una eximente -así, estado de necesidad $-{ }^{57}$. Se refiere a casos en que si bien una sanción penal puede resultar excesiva, sí en cambio puede constituir un efectivo disuasivo de aquellas conductas de carácter mafioso y, a su vez, un incentivo para colaborar con la autoridad al eliminar de la competencia aquellas empresas que nada hacen al respecto ${ }^{58}$. Se trata de medidas dirigidas a evitar el peligro cierto de que organizaciones criminales tomen el control de las concesiones públicas -en el art. 416 bis del Código punitivo que tipifica el delito de asociación de tipo mafioso hace expresa mención-.

b) La otra medida apunta a los gestores de agencias que prestan servicios de transferencia de dinero -los Ilamados money transfer-. Es un mecanismo muy utilizado por ciudadanos extracomunitarios, pues no se requiere ser titular de una cuenta bancaria ni poseer una tarjeta de crédito y el trámite es muy simple: basta poseer un documento de identidad, entregar la suma de dinero que será transferida y los datos del destinatario. Por tal motivo, se puede prestar a ser empleada por la criminalidad organizada, a fin de reciclar dinero de origen ilícito. Precisamente, el Decreto Legislativo No 231 de 2007 -que actúa la Directiva 2005/60/CE relativa a la prevención de la utilización del sistema financiero

\footnotetext{
${ }^{57}$ VIGanò, Francesco, "Mafia e imprenditori: una decisione coraggiosa in tema di stato di necessità", Diritto penale e processo 10, 2004, pp. 1251 y ss., da cuenta del caso de un empresario que fue víctima de una tentativa de extorsión por parte de miembros de una organización mafiosa y que por efecto de las amenazas ocultó información a la policía. Se resolvió eximirlo por concurrir un estado de necesidad.

${ }^{58}$ Así lo estima, Corvı, "Nuove risposte", cit. nota n. 51, p. 350.
} 
con el propósito de reciclar lo que proviene de actividades criminales y de financiamiento del terrorismo- dispone de una serie de requisitos que deben cumplir tales agencias a fin de evitar tal propósito ${ }^{59}$. Entre ellas: a) informar de operaciones frecuentes; b) si bien ocasionales, pero de sumas igual o superiores a 15.000 euros; c) cualquier suma transferida, pero de la que hay sospecha de reciclaje o financiamiento del terrorismo; d) hay dudas sobre la información proporcionada por el cliente. Toda esta información debe ser entregada a la Unità di informazione finanziaria per l'Italia (UIF), que le corresponde la tarea de "vigilar" el sistema financiero italiano.

Si bien se trata de una medida altamente positiva, ofrece importantes vacíos. Por de pronto, no se aplica a los ciudadanos italianos, a los comunitarios y tampoco a los que poseen un permiso de residencia. En definitiva, sólo se dirige a los extracomunitarios sin permiso, por lo que parece más una medida contra la inmigración clandestina que a perseguir el reciclaje. Sin embargo, lo más curioso es que se trata de una clásica norma que tiene un efecto criminógeno evidente. Los inmigrantes ilegales recurrirán a vías clandestinas para enviar dinero a sus familiares, abriéndose de esta forma un nuevo negocio para la criminalidad organizada, que sí dispone de medios para materializar con éxito este "negocio". Además, los riesgos son mínimos, pues sus clientes son inmigrantes ilegales, quienes difícilmente denunciarán a la autoridad tal práctica, si ello le significa dar a conocer su calidad de clandestino ${ }^{60}$.

Por último, tampoco se puede dejar de considerar la existencia de ciertos factores sociales -así, la pobreza, la marginalidad- y culturales -corrupción, democracias poco sólidas- que favorecen el desarrollo de la criminalidad organizada. Por tanto, si se pretende enfrentarla seriamente, deben ser considerados. Aun cuando ambos factores se pueden apreciar en conjunto, los expondré por separado a fin de facilitar la exposición ${ }^{61}$.

Ya se comentó como una de las grandes consecuencias de la globalización es que no sólo ha surgido una especie de macro-criminalidad transnacional, asociada, entre otras actividades delictivas, al blanqueo de capitales, al tráfico de armas y de drogas, es decir, una criminalidad de tipo económica. Sin embargo, también el mayor movimiento de capitales y personas, ha ido generando una especie de micro-criminalidad. Es así, que los flujos migratorios, generalmente ilegales y de personas pobres, dan lugar, entre otros sucesos, a explotación laboral, a la prostitución, microtráfico, conformando bolsones de pobreza,

\footnotetext{
${ }^{59} \mathrm{Al}$ respecto, PISTORELLI, Luca, "La normativa antiriciclaggio introdotta dal d. Lg. 21 novembre 2007, NN 231", Giurisprudenza di merito 10, 2008, pp. 2468 y ss.; CORvı, "Nuove risposte", cit. nota n. 51, pp. 358 y ss.

${ }^{60}$ Con los mismos términos, CoRvı, "Nuove risposte", cit. nota n. 51, p. 362.

${ }^{61}$ Así también lo entiende, ZúÑIGA, Criminalidad organizada, cit. nota n. 6, p. 104.
} 
gérmenes de marginalidad ${ }^{62}$. Precisamente, son estos "nuevos pobres" o mejor dicho, personas que buscando nuevos horizontes, continuarán, en definitiva, manteniendo su condición, sirviendo a estas organizaciones, ya sea para cometer delitos - violencia, tráfico de drogas- o ser objeto de delitos -explotación laboral, sexual, tráfico de órganos- ${ }^{63}$.

La Convención de Palermo se hace cargo de esta cuestión, señalando la necesidad de adoptar medidas de prevención para abordar la pobreza y la marginalidad, pues son factores de los que se aprovecha el crimen organizado. Precisamente, el art. 15. 3 del Protocolo contra el tráfico ilícito de migrantes por tierra, mar y aire, que complementa la Convención de las Naciones Unidas contra la delincuencia organizada transnacional -Convención de Palermo- señala: "Cada Estado Parte promoverá o reforzará, según proceda, los programas y la cooperación para el desarrollo en los planos nacional, regional e internacional, teniendo en cuenta las realidades socioeconómicas de la migración y prestando especial atención a las zonas económica y socialmente deprimidas, a fin de combatir las causas socioeconómicas fundamentales del tráfico ilícito de migrantes, como la pobreza y el subdesarrollo". Asimismo, el art. 9. 4 del Protocolo para prevenir, reprimir y sancionar la trata de personas, especialmente mujeres y niños de la misma Convención dispone: "Los Estados Parte adoptarán medidas o reforzarán las ya existentes recurriendo en particular a la cooperación bilateral o multilateral, a fin de mitigar factores como la pobreza, el subdesarrollo y la falta de oportunidades equitativas que hacen a las personas, especialmente las mujeres y los niños, vulnerables a la trata".

Como se destacó supra la criminalidad organizada crece y se desarrolla en países donde sus instituciones democráticas son poco sólidas, como es el caso de algunos países de América Latina ${ }^{64}$. En dicha región se aprecia una permanente inestabilidad política, constantes casos de corrupción donde se ven involucrados, incluso, altos representantes del gobierno. Todo ello genera una pérdida de confianza por parte de la ciudadanía hacia las autoridades, pues en no pocos casos no son sancionados, percibiéndose una especie de cultura de la impunidad. Pues bien, si a la debilidad del Estado de Derecho se le agrega la perenne desigualdad social imperante, el escaso respeto por los derechos humanos, los espacios que se le ofrecen a grupos criminales organizados son enormes. $\mathrm{Y}$ es que las posibilidades de ser perseguidos y sancionados son

\footnotetext{
${ }^{62}$ SILVA, La expansión, cit. nota n. 9, p. 83; GIASANTI, Alberto, "Marginalità sociale, periferie urbane, racket", en BANDinI, Tullio; Lagazzı, Marco; Marugo, Maria Ida (Edits.), La criminalità organizzata. Moderne metodologie di ricerca e nuove ipotesi esplicative, Giuffrè, Milán, 1993, pp. 165 y ss.

${ }^{63} \mathrm{Al}$ respecto, García, Trata de personas, cit. nota n. 17, p. 141.

${ }^{64}$ RojAS ARAVEnA, Francisco, El crimen organizado internacional: una grave amenaza a la democracia en América Latina y el Caribe, Flacso, San José de Costa Rica, 2006, passim. En: http://www.scribd.com/ doc/2570755/El-crimen-organizado-internacional-amenaza-a-la-democracia [visitado el 20/06/2010]; Solís, Luis Guillermo; Rojas Aravena, Francisco (Edit.), Crimen organizado en América Latina y el Caribe, Catalonia, Santiago, 2008, passim.
} 
mínimas, más aún si existe una suerte de connivencia entre estos grupos y la autoridad pública ${ }^{65}$.

\section{La responsabilidad del ente en los delitos de criminalidad organizada}

En los últimos años el tradicional dogma societas delinquere non potest, muy presente en la cultural jurídico-penal continental, ha cedido su espacio y hoy la gran mayoría de dichas legislaciones sí contemplan disposiciones que penalizan directamente a la corporación ${ }^{66}$.

Como se ha indicado, diversos instrumentos internacionales, ya sea de las Naciones Unidas o de la Unión Europea -en donde los principales destinatarios de sus normas son entidades colectivas ${ }^{-67}$, disponen de la necesidad de adoptar medidas para hacer responsables a las personas jurídicas de los delitos que en ellos se indican ${ }^{68}$.

${ }^{65}$ ZÚÑIGA, Criminalidad organizada, cit. nota n. 6, pp. 110-114.

${ }^{66}$ Para un examen histórico del tema, MARINUCCI, Giorgio, "La responsabilità penale delle persone giuridiche", Rivista italiana di diritto e procedura penale, 2007, pp. 445 y ss.; MIR PUIG, Santiago, Derecho penal. Parte General, $7^{a}$ Edición, Reppertor, Barcelona, 2004, pp. 197-198, expone que si bien en Roma no se consideró la responsabilidad de las personas jurídicas, durante la Edad Media y los Época Moderna sí se admitió. Pero, fue a fines del siglo XVIII cuando el principio societas delinquere non potest adquiere relevancia, fundándose en que para la imposición de penas sólo puede regir el principio de responsabilidad personal. Durante el siglo XIX surgieron una serie de teorías dirigidas a erigir las bases necesarias que permitieran sancionar penalmente a las personas jurídicas -así, la teoría de la realidad de Gierke-. El propio Von Liszt fue partidario de su punición, como se aprecia en su famosa frase: "Quien puede concluir contratos, puede concluir también contratos fraudulentos o usurarios". Consideraba que estos entes podían ser un instrumento peligroso, del que podían servirse los agentes delictivos.

${ }^{67}$ Como primeros trabajos en esta esfera, VV.AA., La responsabilità penale delle persone giuridiche in Diritto comunitario, Giuffrè, Milán,1981. Aquí se puso de manifiesto, que las divergencias en el tratamiento de estos entes podía dificultar el desarrollo de la Comunidad Europea, pues las empresas preferirían aquellos Estados en los que su legislación nada disponga o establezca sanciones más leves. Por tanto, se concluyó la necesidad de reconocer la responsabilidad de estas entidades por violación al Derecho comunitario. Pero, teniendo en cuenta las diferencias existentes entre las diversas legislaciones, se recomendó que cada Estado elaborara un sistema represivo que comprendiera sanciones, sean de naturaleza penal, administrativa o sui generis. FLoRA, Giovanni, "L'attualità del principio 'Societas delinquere non potest'", Rivista trimestrale di diritto penale dell'economia, 1995, p. 14, considera que una aproximación de las legislaciones en este punto es una exigencia vital para el futuro de la Comunidad Europea. Así también, LeIGH, Leonard, "Possibilities for a European Administrative Penal Law", en SIEBER, Ulrich (Edit.), Europäische Einigung und Europäisches Strafrecht, Colonia-Berlín-Bonn-Munich, 1993, p. 114; Castellana, A. M., "Diritto penale dell'Unione Europea e principio 'Societas delinquere non potest'", en Rivista trimestrale di diritto penale dell'economia, 1996, pp. 750 y ss.

${ }^{68}$ AMARELLI, Giuseppe, "La responsabilità delle persone giuridiche e la repressione della criminalità organizzata transnazionale", en PAtalano, Vincenzo (Edit.), Nuove strategie per la lotta al crimine organizzato transnazionale, Giappichelli, Turín, 2003, pp. 32 y ss. 
Un importante papel también le corresponde a la Convención OCDE sobre la lucha a la corrupción de los funcionarios públicos extranjeros en las operaciones económicas internacionales de $1997^{69}$. En los arts. 2 y 3 también se dispone la responsabilidad de las personas jurídicas. Si bien no se exige la imposición de sanciones penales, sí que éstas deben ser eficaces, proporcionales y disuasivas ${ }^{70}$. Asimismo, puede destacarse la Convención sobre criminalidad informática conocida como Convención de Budapest de 2001, que en los art. 12 y 13 también se refiere a la responsabilidad de los entes ${ }^{71}$.

Se entiende que la actividad empresarial ofrece eficaces herramientas para que pueda operar la criminalidad organizada y el terrorismo. Por tanto, se ha estimado indispensable establecer todo un sistema de imputación y tratamiento sancionatorio para el ente, distinto al que corresponde a las personas naturales. Además, puede decirse que existe cierto consenso, desde una perspectiva político criminal, que las nuevas realidades sociales y el rol cada vez más activo y determinante de las entidades colectivas en un mundo económico globalizado dejan ver la insuficiencia de sanciones penales únicamente dirigidas a las personas físicas que obran en su nombre o representación ${ }^{72}$. Además, se trata de contextos despersonalizados, en donde lo relevante no es tanto qué persona física en particular actúa, sino que lo hace por la persona jurídica -muchas veces son sujetos fungibles-. Asimismo, tampoco puede prescindirse del carácter simbólico-comunicativo de las que gozan las sanciones penales, a diferencia de las sanciones administrativas -que generalmente se aplican a las personas jurídicas-, como para no decantarse en esta dirección ${ }^{73}$.

\footnotetext{
${ }^{69}$ Ver Convención En: http://www.mecon.gov.ar/basehome/informes/convencion_cohecho_ocde.pdf [visitado el 21/06/2010].

70 SACERDOtI, Giorgio, "La Convenzione OCSE del 1997 sulla lotta contro la corruzione dei pubblici ufficiali stranieri nella transazioni commerciali internazionali", Rivista italiana di diritto e procedura penale, 1998, pp. 1349 y ss.; HUBER, Barbara, "La lotta alla corruzione in prospettiva sovranazionale", Rivista trimestrale di diritto penale dell'economia, 2001, pp. 467 y ss.; PAtalano, "Profili problematici", cit. nota n. 6, pp. 394-396. En el caso de Chile, la introducción de una sistema de responsabilidad penal de las personas jurídicas Ley $N^{\circ} 20.393$ guarda estrecha relación con su propósito de incorporarse a la OCDE. Al respecto, cfr. HeRNÁNDEZ, Héctor, "La introducción de la responsabilidad penal de las personas jurídicas en Chile", Política Criminal Vol. 9, A5, 2010, pp. 207 y ss. En: http://www.politicacriminal. cl/Vol_05/n_09/Vol5N9A5.pdf [visitado el 30/09/2010]; MATUs, Jean Pierre, "Informe sobre el proyecto de ley que establece la responsabilidad penal de las personas jurídicas en los delitos de lavados de activos, financiamiento del terrorismo y delitos de cohecho que indica, mensaje № 018-357", Revista lus et Praxis Año 15, № 2, 2009, pp. 285 y ss.

${ }^{71}$ Belluta, Hervé, "Cybercrime e responsabilità degli enti", en LuPÁRIA, Luca (Edit.), Sistema penale e criminalità informatica, Giuffrè, Milán, 2009, pp. 83 y ss.

72 Pronunciándose a favor de que las personas jurídicas respondan ex crimine, Paliero, Carlo Enrico, "La società punita: del come, del perchè, e del per cosa", Rivista italiana di diritto e procedura penale, 2008, pp. 1516 y ss.

${ }^{73}$ SILVA, La expansión, cit. nota n. 9, p. 159.
} 
No pretendo acá entrar a examinar la conveniencia o no de introducir el principio societas delinquere potest-del que sí soy partidario-y cuáles pueden ser las repercusiones que su incorporación pueda significar dentro del sistema propio de la teoría del delito y de qué modo hacerlo, sin que ello pueda suponer vulnerar ciertos principios ${ }^{74}$. Lo dejo de lado, no porque su discusión carezca de importancia, sino más bien, porque el objetivo perseguido aquí es otro: analizar de qué forma la responsabilidad penal del ente colectivo puede convertirse en una herramienta eficaz para enfrentar la criminalidad organizada.

\subsection{El Decreto Legislativo No 231 de 2001 que regula la responsabilidad de las personas jurídicas}

Como me centraré en la experiencia italiana, por las razones expuestas supra, expondré someramente el sistema de imputación establecido respecto del ente.

El Decreto Legislativo № 231, de 8 de junio de 2001, introdujo la responsabilidad de las personas jurídicas. Esencialmente para dar cumplimiento a las convenciones europeas ya citadas, particularmente las relativas a la corrupción. En un principio el elenco de delitos que podían atribuirse al ente era bastante reducido, pero con el correr de los años se ha ido ampliando. Es así, que hoy se

\footnotetext{
${ }^{74}$ Es así, que se cuestiona la responsabilidad penal de las personas jurídicas desde la perspectiva de la culpabilidad. Objeción que no se manifiesta cuando se trata de imponer sanciones administrativas a los entes. Si es así, Ilama la atención que se objete, en cambio, la posible imposición de sanciones penales, en circunstancia de que tratándose de las personas jurídicas, la entidad de ambas sanciones son muy similares. Además, tanto el Derecho penal y el Derecho administrativo sancionador son expresiones que conforman lo que se ha dado en Ilamar un Derecho penal en sentido amplio, pues ambos comparten una sustancia común. Si bien existen diferencias entre estas ramas, en lo fundamental constituyen una manifestación de la reacción estatal principalmente represiva. Asimismo, ambos sistemas tienen una vocación preventiva y se hallan "formalizadas", lo que otorga a los destinatarios de las normas el necesario grado de seguridad jurídica. Por lo anterior, para ambos rigen similares principios garantísticos, entre ellos, la culpabilidad. Para PAliero, Carlo Enrico; Travi, Aldo, La sanzione administrativa, Giuffrè, Milán, 1988, pp. 89 y ss., p. 105, en la sanción administrativa se observa también una orientación preventiva general y especial propios de la pena criminal; CARRetero Pérez, Adolfo; CarRetero SánCheZ, Adolfo, Derecho administrativo sancionador, $2^{a}$ Edición, Edersa, Madrid, 1995, p. 173, señalan que cualquiera de las características propias de la pena pueden aplicarse a las sanciones administrativas: finalidad preventiva general y especial, responsabilidad del autor frente al Estado, protección de bienes jurídicos. Por otro lado, la característica fundamental que distingue las sanciones punitivas de las restitutorias, es que en aquéllas son instrumentos preventivos orientados hacia la protección de bienes jurídicos, por tanto, la sanción para el autor de la infracción tiene un carácter aflictivo. En cambio, las medidas resarcitorias pretenden la eliminación del daño causado o del provecho obtenido. La moderna doctrina administrativista es consciente de la proximidad que existe entre ambas ramas y que, en definitiva, son expresiones de un mismo ordenamiento punitivo del Estado. Así, para Nieto García, Alejandro, Derecho administrativo sancionador, $2^{a}$ Edición, Tecnos, Madrid, 1994, pp. 167-168, la discusión no se centra en "si" deben aplicarse los principios de Derecho penal, sino "qué" principios y "hasta qué punto". Bajo esta perspectiva, este autor señala que deben imponerse los principios punitivos constitucionalizados, que se entienden comunes a todo el ordenamiento punitivo del Estado, aunque procedan del Derecho penal.
} 
comprenden delitos de diversa naturaleza. Sólo por citar algunos: delitos contra la Administración pública, delitos societarios, abusos de mercado, homicidio o lesiones culposas en materia laboral, delitos con finalidad terrorista o de subversión, prácticas de mutilación de órganos genitales femeninos, esclavitud, prostitución de menores o pornografía infantil. En 2009 se introdujeron los delitos de criminalidad organizada -art. 24 ter del Decreto Legislativo $N^{\circ} 231-$, sobre los cuales dirigiré mi atención. Como se aprecia, se trata de delitos, si bien diversos en cuanto su naturaleza, sí pueden ser cometidos por entes. Algunos de ellos responden a las exigencias dispuestas por la Convención de Palermo para perseguir el crimen organizado transnacional, como es el caso de la trata de personas -esclavitud, prostitución de menores-.

Todo indica que el catálogo se irá ampliando. Por de pronto, la Directiva europea 2008/99/CE ${ }^{75}$ sobre la protección penal del medio ambiente, dispone en su art. 6 la responsabilidad de las personas jurídicas. Normativa que los países miembros deben traspasar a sus ordenamientos internos.

Se ha discutido si la responsabilidad del ente es administrativa o penal. Si bien es cierto el Decreto Legislativo $N^{\circ} 231$ habla de responsabilidad administrativa, todo parece indicar que es más bien penal ${ }^{76}$. En efecto, se trata de responsabilidad por la comisión de delitos; se establecen criterios de imputación que relacionan a una persona física que actúa en interés o para obtener una ventaja para la persona jurídica. Precisamente esto último permitiría salvar las objeciones que pueden provenir del art. 27 inc. 1 de la Constitución italiana que dispone: "La responsabilidad penal es personal", por cuanto la responsabilidad del ente y su culpabilidad se determina sobre la base de la conducta de un sujeto que actúa como "organización"777; por último, es un juez penal el llamado a juzgar la responsabilidad del ente colectivo.

\footnotetext{
${ }^{75}$ Ver En: http://eur-lex.europa.eu/LexUriServ/LexUriServ.do?uri=OJ:L:2008:328:0028:0037:ES:PDF [visitado el 12/06/2010]. Cfr. ARENA, Maurizio; CASSANO, Giuseppe, La responsabilità da reato degli enti collettivi, Giuffrè, Milán, 2007, pp. 44 y ss.

${ }^{76}$ Amarelli, "La responsabilità", cit. nota n. 68, pp. 26-27; para FiAndaCa, Giovanni/Musco, Enzo, Diritto penale. Parte generale, $5^{a}$ Edición, Zanichelli Editore, Boloña, 2008, p. 163, el calificar de administrativa la responsabilidad de la persona jurídica sería más bien un fraude de etiquetas, pues sustancialmente tiene un carácter penal; PADOVANI, Tullio, "Il nome dei principi e il principio dei nomi: la responsabilità "amministrativa" delle persone giuridiche", en De FranCESCO, Giovannangelo (Edit.), La responsabilità degli enti: un nuovo modello di giustizia "punitiva", Giappichelli, Torino, 2004, pp. 13 y ss.

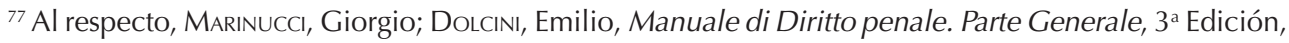
Giuffrè, Milán, 2009, p. 144. En todo caso, estos autores son del parecer que la elección del legislador de llamar responsabilidad administrativa no constituye un fraude de etiquetas (p. 145). Para DE MAGLIE, Cristina, L'etica e il mercato. La responsabilità penale della società, Giuffrè, Milano, 2002, pp. 341 y ss., el art. 27 de la Constitución no impediría disponer la responsabilidad penal del ente, pues cuando se habla de responsabilidad personal se refiere "a hechos propios" y lo que se prohíbe es responder "por hechos ajenos". Por tanto, no hay una exclusión a priori de las personas jurídicas.
} 
En cuanto a los criterios de atribución de responsabilidad de la persona jurídica, se deben distinguir dos: a) Art. 5. La infracción penal haya sido cometida en su interés o para su ventaja por quienes se encuentran en posición jerárquica superior o por sujetos subordinados a la dirección o vigilancia de aquéllos. No cabe imputar al ente, como es de suponer, si estos sujetos han obrado en exclusivo interés propio o de terceros ${ }^{78} ;$ b) Arts. 6 y 7 . Determinar la llamada culpa por organización, esto es, la carencia de elección o la actuación deficiente de un modelo de organización o de gestión que sean idóneos para la prevención de delitos. Así también, cuando no se ha confiado la función de vigilancia o la observancia de los modelos de organización a un organismo autónomo al ente ${ }^{79}$.

La culpa por organización no constituye ninguna novedad, pues ya había sido expuesta en 1988 por Tiedemann para fundamentar la capacidad de acción y de culpabilidad de las personas jurídicas ${ }^{80}$. Este autor sostiene que el hecho de que existan normas que se dirijan "directamente" a entes supraindividuales, se debe a que el legislador los estima con capacidad para realizar aquellas conductas antijurídicas establecidas en la norma, es decir, que pueden con su comportamiento lesionar un bien jurídico. El que materialmente la corporación lleve a cabo sus actuaciones a través de personas físicas -órganos o representantes- nada impide que pueda sostenerse la capacidad de acción de la empresa. En efecto, mediante la teoría de la imputación de hechos ajenos a la

${ }^{78}$ SelvagGi, Nicola, L'interesse dell'ente collettivo. Quale criterio di ascrizione della responsabilità da reato, Jovene Editore, Nápoles, 2006, passim; BernAsConı, Alessandro, "Art. 5", en PresutTI, Adonella; BernasConı, Alessandro; FIORIO, Carlo, La responsabilità degli enti. Commento articolo per articolo al D. Legisl. 8 giugno 2001 NNo 231, Cedam, Padua, 2008, pp. 97 y ss.; Pulitanò, Domenico, "La responsabilità 'da reato' degli enti: i criteri d'imputazione", Rivista italiana di diritto e procedura penale, 2002, pp. 425 y ss.; De VERO, Giancarlo, "Struttura e natura giuridica dell'illecito di ente collettivo dipendente da reato", Rivista italiana di diritto e procedura penale, 2001, pp. 1154 y ss.; MARENGHI, "La responsabilità", cit. nota n. 52, pp. 276 y ss.

${ }^{79}$ AlESSANDRI, Alberto, "Riflessioni penalistiche sulla nuova disciplina", en VV.AA., La responsabilità ammnistrativa degli enti, Ipsoa, Milán, 2002, pp. 25 y ss.; AlESSANDRI, Alberto, "Note penalistiche sulla nuova responsabilità delle persone giuridiche", Rivista trimestrale di diritto penale dell'economia 2002, pp. 50 y ss.; PALIERO, Carlo Enrico, "La responsabilità delle persone giuridiche: profili generali e criteri di imputazione", en AlesSANDRI, Alberto (Edit.), Il nuovo diritto delle società, Ipsoa, Milán, 2002, pp. 47 y ss.; SFAMENI, Paolo, "La responsabilità delle persone giuridiche: fattispecie e disciplina dei modelli di organizzazione, gestione e controllo", en AlESSANDRI, Alberto (Edit.), Il nuovo diritto delle società, Ipsoa, Milán, 2002, pp. 65 y ss.; TRIPODI, Andrea Francesco, "'Situazione organizzativa' e 'colpa in organizzazione': alcune riflessioni sulle nuove specificità del diritto penale dell'economia", Rivista trimestrale di diritto penale dell'economia, 2004, pp. 483 y ss.; De MAGLIE, Cristina, "Principi generali e criteri di attribuzione della responsabilità", Diritto penale e processo 11, 2001, pp. 1348 y ss.; GARGANI, Alberto, "Imputazione del reato agli enti collettivi e responsabilità penale dell'intraneo: due piani irrelati?", Diritto penale e processo 9, 2002, pp. 1061 y ss.; MANNA, Adelmo, "La c.d. reponsabilità amministrativa delle persone giuridiche: un primo sguardo d'insieme", Rivista trimestrale di diritto penale dell'economia, 2002, pp. 507 y ss.

${ }^{80}$ TIeDEMANN, Klaus, “Die 'Bebußung' von Unternehmen nach dem 2.Gesetz zur Bekämpfung des Wirtschaftskriminalität", Neue Juristische Wochenschrift, 1988, pp. 1169 y ss. 
persona jurídica, es posible atribuirle la actuación de sus órganos o representantes, pues en definitiva, la persona jurídica ha actuado a través de éstos, se trata de hechos que sólo, formalmente, le son ajenos ${ }^{81}$. En lo que respecta a la capacidad de culpabilidad propia de los entes colectivos, Tiedemann la construye conforme a la llamada "culpabilidad de organización" (Organisationsverschulden), la que se fundamenta en que la empresa, al no haber organizado su actividad-por medio de sus representantes u órganos- de acuerdo a lo que era exigible por el ordenamiento, ha generado las posteriores comisiones delictivas, que han tenido lugar al haber omitido tomar las medidas de cuidado que son necesarias para asegurar la realización de negocios ordinarios. Esta clase de culpabilidad se estructura de una manera similar a como lo hace la culpabilidad por un hecho anterior -ya admitida para los casos de actio libera in causa-. Si las infracciones que ha cometido la persona física al interior de la empresa han tenido lugar por la no adopción previa de medidas necesarias dirigidas a evitar tales comportamientos posteriores, esto último le debe ser imputado al ente colectivo. Se ha criticado la teoría de culpabilidad por organización de Tiedemann, en cuanto podría constituirse en un principio de responsabilidad que no admita prueba en contrario ${ }^{82}$. Esto es, como ha señalado Brender ${ }^{83}$-quien elabora el concepto de responsabilidad principal (Hauptverschulden) ${ }^{84}$ para fundamentar la imputación de la persona jurídica una vez establecido el hecho de contacto, es decir, el comportamiento ilícito de la persona natural-, al ser la noción de deficiencia en la organización o insuficiencias en los deberes de vigilancia por parte de la empresa, conceptos ficticios, el ente supraindividual deberá responder, imputándole el ilícito, un vez comprobado el hecho de contacto. Conforme a esta argumentación, no tendrá relevancia que la empresa alegue haber empleado todos los medios necesarios de control y que aún así, nada pudo hacer para evitar la infracción, pues deberá igualmente responder por las actuaciones de sus órganos o representantes. Ahora bien, podría criticarse esta última construcción doctrinal, en que lo propio sería mantener las esferas de imputación diferenciadas y reconocer que existe una culpabilidad propia de la persona jurídica, cosa que, en definitiva, se niega con esta argumentación, pues el que se impute sin más al ente colectivo, una vez acreditado el hecho de contacto, nos estaría indicando que sólo a la persona natural se le puede reconocer la culpabilidad. La responsabilidad de la persona jurídica deberá nacer de su propia conducta -sujeto activo de un ilícito-, por haber quebrantado el deber de evitar la comisión de infracciones, obligación ésta que emana del propio ordenamiento jurídico.

La estructura de los modelos de organización o de gestión dispuestos en la legislación italiana que se inspiran en la regulación norteamericana -conocidos

${ }^{81}$ Como subraya Tiedemann, Klaus, Lecciones de Derecho penal económico (Comunitario, español, alemán), PPU, Barcelona, 1993, p. 234, la imputación de hechos ajenos se conoce en otras esferas del Derecho penal. Así también en el ámbito de la coautoría, o en la autoría mediata.

${ }^{82}$ Cfr. al respecto, Tiedemann, "Die 'Bebußung'”, cit. nota n. 80, p. 1173.

${ }^{83}$ BRENDER, Markus, Die Neuregelung der Verbandstäterschaft im Ordnungswidrigkeitenrecht, Friburgo, 1989, pp. 101 y ss.

${ }^{84}$ Brender, Die Neuregelung, cit. nota n. 83, pp. 110 y ss. 
como compliance programs $s^{85}$ - tienen como propósito, tanto la individualización de los ámbitos de riesgo para el ente en cuanto a la posible comisión de delitos, de modo de prevenirlos, como también disponer de mecanismos de actuación y de procedimientos a seguir por quienes se encuentran ya sea en posición superior o subordinada.

La normativa italiana brinda especial atención e importancia a los aspectos organizativos de las empresas: debe adoptarse y llevarse a cabo un modelo de gestión dirigido a impedir la comisión de infracciones penales; la conformación de un organismo dirigido a vigilar el funcionamiento y la observación de este modelo, y la estructuración de un sistema disciplinario interno ${ }^{86}$.

Para los efectos probatorios -art. 6- se debe distinguir si la infracción es cometida por quien se halla en una posición apical o subordinada -distinción que obedece a la distinta capacidad de influir en las políticas empresariales-. Tratándose de los primeros, la carga de la prueba recae en el ente. Éste debe acreditar la ausencia de culpa por organización, es decir, debe probar, que aun cuando el modelo de organización era eficaz como mecanismo de control, la persona jurídica no tenía la capacidad de impedir la comisión de delitos por parte de los sujetos en posición jerárquica superior. Éstos, como señala la letra c) del inc. 1 del art. 6, han obrado "eludiendo fraudulentamente los modelos de organización y de gestión". En cambio, respecto a las infracciones penales cometidas por aquellos sujetos subordinados a la dirección o vigilancia de otros -art. 7-, la carga de la prueba recae en el Ministerio Público, el que debe acreditar el funcionamiento inadecuado del modelo de organización o, en su caso, de los organismos de control.

Como se ha señalado, la culpa por organización es uno de los criterios para poder atribuir responsabilidad al ente. Pues bien, de lo anterior se desprende que como presupuesto mínimo para poder imputar se admite la culpa -así por ejemplo, no haber obrado diligentemente en el reconocimiento del peligro de comisión de un delito- ${ }^{87}$. En algunos casos, la propia ley dispone la exigen-

\footnotetext{
${ }^{85}$ AldRovandi, Paolo, "I «modeli di organizzazione e di gestione» nel D. Lgs. 8 giugno 2001, № 231: aspetti problematici dell' "ingerenza penalistica» nel "governo» delle società", Rivista trimestrale di diritto penale dell'economia, 2007, pp. 460 y ss.; De MAGLIE, Cristina, "Sanzioni pecuniarie e tecniche di controllo dell'impresa. Crisi e innovazioni nel diritto penale statunitense", Rivista italiana di diritto e procedura penale, 1995, p. 118 y ss.; DE VERO, "Struttura e natura", cit. nota n. 78, pp. 1132 y ss.; BARTOLOMUCCI, Sandro, Corporate governance e responsabilità delle persone giuridiche, Ipsoa, Milán, 2004, pp. 8 y ss.

${ }^{86}$ MONESI, Carlo (Edit.), I modelli organizativi ex D. Lgs. 231/2001. Etica d'impresa e punibilità degli enti, Giuffrè, Milán, 2005, p. 251 y ss.; Bernasconi, Alessandro, "Art. 6", en Presutti, Adonella; Bernasconi, Alessandro; Fiorıo, Carlo, La responsabilità degli enti. Commento articolo per articolo al D. Legisl. 8 giugno 2001 NN$^{\circ}$ 231, Cedam, Padua, 2008, pp. 109 y ss.

${ }^{87}$ Así lo sostienen MarinucCl; Dolcinl, Manuale, cit. nota n. 77, p. 148; Paliero, Carlo Enrico, "La responsabilità penale della persona giuridica nell'ordinamento italiano: profili sistematici", en PALAzzo,
} 
cia de una actuación dolosa del ente. En efecto, diversas hipótesis delictivas consagradas en el Decreto Legislativo $N^{\circ} 231$ se refieren a aquellos casos en que se aprecia una política de empresa de carácter criminal, esto es, hacia la comisión de delitos. Es el caso, por ejemplo, de los art. 25 quáter sobre delitos con finalidad de terrorismo o de subversión del orden democrático o art. 24 ter sobre delitos de criminalidad organizada -que será examinado infra-. Ambos contemplan el supuesto de que "el ente o su unidad organizativa es constantemente utilizado con el propósito único o prevalente de consentir o facilitar la comisión" del delito.

En estos casos se contempla la sanción de interdicción definitiva del ejercicio de la actividad empresarial regulada en el art. 16 inc. 3. Sin embargo, este mismo artículo dispone esta sanción para cualquier delito consagrado en el decreto examinado, si se aprecia el mismo comportamiento descrito más arriba: "el ente o su unidad organizativa es constantemente utilizado con el propósito único o prevalente de consentir o facilitar la comisión".

Por último, en este rápido examen del Decreto $\mathrm{N}^{\circ} 231$, cabe destacar que el elenco de sanciones se encuentra en el art. $9^{88}$ : a) La sanción pecuniaria -arts. 10 y $11-$, que se precisa de conformidad a cuotas. A fin de calcularlas el juez debe considerar la gravedad del hecho, el grado de la responsabilidad del ente y a la actividad desarrollada para eliminar o atenuar las consecuencias del hecho o para prevenir la reiteración; b) las sanciones interdictivas, que pueden ser temporales o definitivas. Respecto de las temporales -arts. 13 y 14- pueden consistir, entre otras: interdicción del ejercicio de la actividad; suspensión o revocación de autorizaciones, licencias o concesiones; prohibición de contratar con la Administración pública. La determinación de cuál de ellas se impondrá la resuelve el juez conforme a criterios como reiteración de los ilícitos, provecho de entidad relevante por parte del ente si la infracción penal es cometida por sujetos en posición apical, graves carencias organizativas si el hecho es cometido por sujetos subordinados a otra dirección; las sanciones interdictivas definitivas -art. 16- se aplican cuando el ente ha obtenido un provecho de relevante entidad y ha sido ya condenado al menos en tres oportunidades en los últimos siete años a la interdicción temporal, o bien cuando

Francesco, Societas puniri potest. La responsabilità da reato degli enti collettivi, Cedam, Padua, 2003, pp. 29 y ss.

${ }^{88}$ Un examen de las sanciones en Angelinl, Marco, "Art. 9", en Presutti, Adonella; Bernasconl, Alessandro; FIOrıo, Carlo, La responsabilità degli enti. Commento articolo per articolo al D. Legisl. 8 giugno 2001 $N^{\circ}$ 231, Cedam, Padua, 2008, pp. 173 y ss.; MucCIARELL, Francesco, "Le sanzioni interdittive temporanee nel D. Lgs. No 231/2001", en Dolcinı, Emilio; Paliero, Carlo Enrico (Edits.), Studi in onore di Giorgio Marinucci. T. III, Giuffrè, Milán, 2006, pp. 2489 y ss.; GıAvAzzı, Stefania, "Le sanzioni interdittive e la publicazione della sentenza penale di condanna", en VV.AA., La responsabilità ammnistrativa degli enti, Ipsoa, Milán, 2002, pp. 119 y ss. 
el ente o su unidad organizativa es constantemente utilizado con el propósito único o prevalente de consentir o facilitar la comisión de infracciones penales; prohibición definitiva de contratar con la Administración pública o prohibición de publicitar bienes o servicios, aplicable cuando el ente ha sido condenado a la misma sanción al menos tres veces en los últimos siete años; c) la confiscación -art. 19- del precio o del provecho del delito, siempre que se establezca en la sentencia de condena, salvo los derechos de terceros de buena fe. Cuando no es posible confiscar el provecho o el precio, la confiscación tendrá por objeto sumas de dinero, bienes u otra utilidad de valor equivalente al precio o al provecho de la infracción penal; d) la publicación de la sentencia de condena -art. 18-, el juez puede disponerla cuando respecto del ente se le aplica una sanción interdictiva.

Para Marinucci y Docini ${ }^{89}$ la eficacia disuasiva de este aparato sancionatorio es más bien modesta, salvo para los casos en que se aplica una sanción interdictiva definitiva. Las sanciones pecuniarias tendrían, de forma abstracta, una apreciable eficacia disuasiva, sin embargo, las hipótesis individuales de infracción penal atribuibles al ente prevén cuotas en número muy inferiores. En cuanto a las sanciones interdictivas temporales y definitivas, aun cuando son conminadas para las hipótesis individualizadas de delitos atribuibles al ente, su aplicación con la sentencia de condena aparece sólo en presencia de condiciones, fácticas o temporales, que acontecen muy raramente, como la hipótesis de la constante utilización del ente para facilitar la comisión del delito. Por ello la tendencia de la jurisprudencia a aplicar por vía cautelar las sanciones interdictivas temporales.

\subsection{Ley No 94 de 2009 que introduce el art. 24 ter-delitos de criminalidad organizada- al Decreto Legislativo No 231}

Como se resaltó precedentemente, si bien la Ley № 146 de 2006 se hizo cargo de la responsabilidad de la persona jurídica respecto de los delitos de criminalidad organizada, lo limitó a aquellos casos en que el delito tuviera un carácter transnacional. Por tanto, se presentaba un vacío cuando las actividades del ente sólo estuvieran vinculadas a la criminalidad organizada "interna" o nacional. Justamente la Ley № 94 de 15 de julio de 2009 -conocida en Italia como el "paquete de seguridad 2009"90-, con la inclusión del art. 24 ter en el

\footnotetext{
${ }^{89}$ MarinuCCI; DolCINI, Manuale, cit. nota n. 77, p. 150.

${ }^{90}$ Cabe destacar que también en 2008 por Ley № 125 de 24 de julio se establecieron "Medidas urgentes en materia de seguridad pública". Esta norma, junto con la Ley № 94 de 2009, conforman el Ilamado "paquete de seguridad". Ambas contienen un heterogéneo conjunto de disposiciones que inciden en el Derecho penal, procesal penal, penitenciario. Así, por ejemplo, en materia de inmigración, de tráfico vial, de delitos sexuales contra menores, de confiscación. Para una visión completa de ambas leyes, Mazza, Oliviero; Vıganò, Francesco (Edits.), Misure urgenti in materia di
} 
Decreto Legislativo $\mathrm{N}^{\circ} 231$, dispone las medidas necesarias a fin de que las personas jurídicas puedan responder por aquellos delitos en que ha participado en una organización criminal.

En todo caso, tampoco puede decirse que el Decreto Legislativo № 231 no contemplaba ya normas que pudieran comprender la imputación de la persona jurídica dentro de actividades propias de la criminalidad organizada. En efecto, el art. 25 quáter se refiere al financiamiento del terrorismo; el art. 25 octies, entre otros, a la receptación, blanqueo de dinero de proveniencia ilícita. Además y como ya se ha hecho presente, el Decreto en cuestión se hace cargo de aquellos casos en que el ente podría calificarse de intrínsecamente ilícito: el art. 16. 3. señala "si el ente o su unidad organizativa es constantemente utilizado con el propósito único o prevalente de consentir o facilitar la comisión de delitos". Para estos casos se dispone la sanción más rigurosa, a saber, la interdicción definitiva.

Empero, el nuevo art. 24 ter amplía el catálogo de delitos atribuibles a la persona jurídica a los delitos asociativos y que se relacionan con la criminalidad organizada. Al respecto, es preciso distinguir dos grupos de delitos-presupuesto: a) asociación para delinquir dirigida a la trata de personas, favorecimiento de la inmigración clandestina, entre otras -art. 416 inciso $6^{\circ}$ del Código Penal italiano-; asociación de tipo mafioso -art. 416 bis del mismo Código-; secuestro de personas con propósito de extorsión -art. 630 del Código Penal-; asociación para el tráfico ilícito de estupefacientes -art. 74 Decreto del Presidente de la República № 309 de 9 de octubre de 1990-; b) asociación para delinquir del art. 416 con excepción del inciso $6^{\circ}$; delitos en materia de armas -art. 407 inciso $2^{\circ}$ letra a) $\mathrm{N}^{\circ} 5$ del Código Procesal Penal italiano-. Ambos grupos se distinguen fundamentalmente por la sanción, siendo menos severa respecto del segundo grupo, por cuanto comprende un delito asociativo común.

Se trata de un elenco de delitos que fundamentalmente se relacionan por cuanto abarcan delitos particularmente graves, vinculados con actividades propias de la criminalidad organizada. En este sentido, se subsumen supuestos asociativos en que se determina el objeto del programa criminal -delitos-finescomo son los casos del tráfico ilícito de estupefacientes, de armas, secuestro con fines de extorsión. Asimismo, se incluyen aquellos casos en que se actúa para favorecer o facilitar las actividades de otras asociaciones criminales, como se desprende del hecho que se comprendan los dos más importantes delitos-

sicurezza pubblica, Giappichelli, Turín, 2008, passim; Mazza, Oliviero; Viganò, Francesco (Edits.), II "pachetto" sicurezza 2009, Giappichelli, Turín, 2009, passim; Corbetta, Stefano; Della Bella, Angela; GatTA, Gian Luigi (Edit.), Sistema penale e "sicurezza pubblica": le riforme del 2009, Ipsoa, Milán, 2009, passim; Amato, Giuseppe; Santoriello, Ciro, Misure urgenti in materia di sicurezza pubblica, Utet, Turín, 2009, passim. 
medio que conoce el ordenamiento penal italiano, a saber, la asociación para delinquir del art. 416 y la asociación de tipo mafioso del art. 416 bis.

Precisamente esta última decisión legislativa, en particular respecto del art. 416, ha sido objeto de crítica por parte de la doctrina, pues ahora cualquier delito puede ser objeto del programa criminal ${ }^{91}$. Con ello se amplían considerablemente los supuestos típicos que se le pueden atribuir al ente, excluyéndose sólo aquellos delitos que por su naturaleza no pueden ser realizados en su interés o ventaja ${ }^{92}$. A lo anterior debe agregarse la circunstancia relativa a la anticipación de la punibilidad que es consustancial a todo delito asociativo. En consecuencia, puede plantearse que el ente responda por los actos preparatorios de cualquier delito si se determina que es parte de un programa criminal de una asociación. En más, podría aplicarse la figura del art. 24 ter, en lo que dice relación al art. 416 del Código penal, cuando tres o más sujetos que se encuentran en una posición jerárquica superior dentro de una misma empresa deciden cometer, por ejemplo, delitos societarios en interés del ente. Este último puede ser sancionado, aun cuando en rigor los delitos no hayan alcanzado la tentativa y sin que sea necesario tener que aplicar la figura del art. 25 ter ya contemplada en el Decreto $N^{\circ} 231^{93}$.

Por lo anterior es que esta figura pueda ser empleada, sin que se trate de delitos que puedan tener alguna relación con la criminalidad organizada, desvirtuándose, de este modo, el sentido original que se pretendía con la incorporación del art. 24 ter.

A los anteriores cuestionamientos, debe agregarse la enorme dificultad que puede representar para las personas jurídicas la construcción de modelos de organización. En efecto, la circunstancia de incluir formas asociativas respecto de cualquier delito, torna especialmente ardua la búsqueda de reglas que permitan individualizar los riesgos de comisión de delitos ${ }^{94}$. Al respecto, sólo puede pensarse que tratándose de empresas que pretenden cometer delitos dentro de la esfera de la criminalidad organizada difícilmente se han elaborado modelos de organización, o de haberlos implantado no los observarán ni actuarán conforme a ellos. Por el contrario, la regla general es que son entidades que ya nacen con propósitos ilícitos o con posterioridad pasan a serlo. Es por ello que en estos casos no parece relevante determinar la culpa por organización,

\footnotetext{
${ }^{91}$ Scoletta, Marco, "Art. 24-ter, d. Igs. № 231/2001", en Corbetta, Stefano; Della Bella, Angela; Gatta, Gian Luigi (Edits.), Sistema penale e "sicurezza pubblica": le riforme del 2009, Ipsoa, Milán, 2009, p. 375.

${ }^{92}$ Para CORvı, "Nuove risposte", cit. nota n. 51, p. 367, la responsabilidad de la persona jurídica de fragmentaria pasa ahora a ser general.

${ }^{93}$ Así lo hacer ver Corvı, "Nuove risposte", cit. nota n. 51, pp. 367-368.

${ }^{94}$ SCOletta, "Art. 24-ter", cit. nota n. 91, p. 379.
} 
derechamente se está frente a un caso de dolo de la persona jurídic $a^{95}$. Por lo demás, debe considerarse que el sentido original y toda la estructura de imputación regulada en el Decreto Legislativo № 231 se ha entendido dirigida a empresas que persiguen fines lícitos y que, eventualmente, en el ejercicio de sus actividades cometen delitos. La comprensión de una empresa criminal resulta de algún extraño y cuando lo ha hecho, como en el caso del art. 16.3 -"el ente o su unidad organizativa es constantemente utilizado con el propósito único o prevalente de consentir o facilitar la comisión de infracciones penales" - se ha entendido esencialmente para los efectos sancionatorios.

Por lo recién expuesto, es que los mayores problemas que se pueden presentar guardan relación con aquellas personas jurídicas que sí persiguen fines lícitos, pero que en el ejercicio de su actividad se aprovechan para la comisión de delitos de una organización criminal. Por ejemplo, miembros de una empresa que ejercen una posición jerárquica superior son, además, miembros de una organización criminal de tipo mafioso conforme al art. 416 bis. Pues bien, si se determina que aprovechándose de esta última asociación -por ejemplo, ha empleado métodos de intimidación- han conseguido a favor de su empresa un contrato público que le genera importantes ganancias, la persona jurídica responderá conforme a lo dispuesto en el art. 24 ter.

También puede acontecer una situación inversa, esto es, que sea la persona jurídica "lícita" la que colabora con una organización de tipo mafioso. Por ejemplo, los miembros de una sociedad que ocupan una posición jerárquica superior, sin ser miembros de la organización criminal, le prestan toda su asesoría o asistencia para que tal organización pueda adjudicarse determinados contratos públicos y ello, a su vez, le reporta un interés al ente, por cuanto será contratada para futuros trabajos.

Este es uno de los casos más discutidos en la doctrina italiana, ¿cómo castigar a quienes no siendo miembros de la asociación ilícita colaboran con ella? En casos similares respecto de personas naturales se ha aplicado el llamado concurso externo en delitos asociativos ${ }^{96}$.

\footnotetext{
${ }^{95}$ CORvı, "Nuove risposte", cit. nota n. 51, p. 375.

${ }^{96}$ La literatura es abundante, sólo por citar algunos trabajos, PICOTTI, Lorenzo; ForNASARI, Gabriele; VIGanò, Francesco; MelChIONDA, Alessandro (Edits.), I reati associativi: paradigmi concettual e materiale probatorio, Cedam, Padua, 2005, passim; INSOLERA, Gaetano, "Ancora sul problema del concorso esterno nei delitti associativi", Rivista italiana di diritto e procedura penale, 2008, pp. 632 y ss.; AlEO, Sistema penale, cit. nota n. 22, pp. 228 y ss.; VISCONTI, Costantino, "Il concorso esterno nell'associazione mafiosa: profili dogmatici ed esigenze politico-criminali", Rivista italiana di diritto e procedura penale, 1995, pp. 1303 y ss.; VISCONTI, Costantino, "Il concorso esterno tra aspetti di costituzionalità e prospettive di riforma legislativa", Diritto penale e processo 6, 1998, pp. 751 y ss.; MANNA, Adelmo, "L'ammisibilità di un c.d. concorso "esterno" nei reati associativi, tra esigenze di politica criminale e principio di legalità", Rivista italiana di diritto e procedura penale, 1994, pp. 1189 y ss.; MusCATIELLo, Vincenzo Bruno, "Per una caratterizzazione semantica del concorso esterno", Rivista italiana di diritto
} 
Hay dos casos emblemáticos en que se discutió la aplicación del concurso externo: Carnevale ${ }^{97}$ y Mannino ${ }^{98}$. Respecto del primero, Carnevale fue Presidente de la primera sección de la Suprema Corte de Casación y durante los años ochenta se lo cuestionó por haber absuelto, argumentando vicios de forma, a un importante número de acusados en procesos seguidos en contra de la mafia. Fue sometido a proceso por concurso externo en asociación mafiosa y suspendido de sus funciones judiciales. Si bien se lo absolvió en primera instancia, en 2001 fue condenado por la Corte de Apelaciones de Palermo a la pena de seis años de presidio. Luego, en 2002 la Corte de Casación lo absolvió. En el segundo caso, Mannino, que es un político que ha desempeñado en diversas oportunidades los cargos de ministro de Estado, fue arrestado en 1995 por un presunto acuerdo con la mafia. Se le imputaba que concedía favores a la mafia para obtener votos. Si bien fue absuelto en primera instancia, fue condenado en la segunda instancia a la pena de cinco años de presidio. Sentencia esta última que fue anulada por la Corte de Casación. En definitiva, en octubre de 2008 fue absuelto por la Corte de Apelaciones de Palermo.

En términos muy generales, la figura del concurso externo se ha aplicado en Italia para enfrentar la criminalidad de tipo mafioso y terrorista, castigando a aquellos sujetos que siendo extraños y no formando parte de la asociación criminal, cooperan con ella, favoreciendo con ello a la asociación criminal. La discusión se ha presentado, por cuanto al no formar parte de la asociación no realiza en rigor una conducta típica: no es un "asociado". Por tanto, no podría contribuir materialmente en la causación del hecho delictivo quien no forma parte de la asociación. Al respecto, hay que tener presente que en Italia se ha optado por un modelo unitario de autor -arts. 110 y ss. del Código Penal-, por lo que todos aquellos que concurren, cualquiera sea la contribución, a la causación del hecho delictivo responden como intervinientes del mismo ${ }^{99}$. Ello no significa, claro está, que todos respondan con la misma pena, sino que ésta se gradúa dentro de un mismo marco penal, precisándose para los distintos intervinientes conforme concurran o no ciertas circunstancias señaladas en el art. 133 del Código Penal.

Señalan Marinucci/Dolcini respecto a la adopción de un modelo unitario: "La razón político criminal de esta elección legislativa reside en el justo convencimiento que la predeterminación de una pena en abstracto más elevada para el autor respecto al partícipe chocaría violentamente con la realidad de las cosas: en particular, no tendría sentido sancionar siempre y de todos modos al ejecutor del delito de forma más severa

e procedura penale, 1999, pp. 184 y ss.; BertorotTA, Francesco, "Concorso eventuale di persone e reati associativi", Rivista italiana di diritto e procedura penale, 1998, pp. 1273 y ss.

${ }^{97}$ Corte de Cassazione, Foro Italiano, II, 2003, pp. 454 y ss.

${ }^{98}$ Corte de Cassazione, Foro Italiano, II, 2006, pp. 80 y ss.

${ }_{99}$ Cfr. Dolcini, Emilio; MarinucCl, Giorgio (Edits.), Codice Penale commentato, T. I. $2^{\text {a }}$ Edición, Ipsoa, Milán, 2006, pp. 1104 y ss. 
que el mandante, puesto que este último, en muchos casos, maneja los hilos permaneciendo en la sombra y asume la parte menos riesgosa, pero más importante de la empresa criminal"100.

Pues bien, tratándose los delitos asociativos, se ha señalado a favor del concurso externo que quien ocasionalmente realiza actividades que refuerzan a la asociación criminal, sí está facilitando su existencia; es decir, quien contribuye dolosamente a reforzar la asociación, sabiendo que su conducta tendrá esta eficacia favorecedora para la asociación, también concurre en la comisión del delito asociativo ${ }^{101}$.

La pregunta que surge es cómo debe responder la persona jurídica en estos casos. Aun cuando no se ha discutido mayormente el punto, se ha señalado que también podría aplicarse la regla del concurso externo ${ }^{102}$. En efecto, la responsabilidad del ente tendrá lugar, determinando en primer lugar si se está o no frente a un concurso externo, aplicando para ello las reglas precedentes y que se han desarrollado respecto de las personas físicas -arts. 110 y 416 ó 416 bis- para, a continuación, acreditar si aquello se ha realizado en su interés o le ha reportado una ventaja -arts. 5, 6 y 7 del Decreto Legislativo No 231-.

Dado que el art. 24 ter es una disposición reciente -julio de 2009- no hay mayores pronunciamientos por parte de la jurisprudencia que permita aquilatar cuán eficiente puede ser la imputación penal de los delitos de criminalidad organizada a la persona jurídica. Sin embargo, y como primera aproximación me merece un juicio positivo. Ya se destacó supra que la criminalidad organizada es eminentemente económica, su fin es el lucro, enriqueciéndose ilícitamente. Por tanto, en este contexto deben contemplarse medidas dirigidas a "dificultar" la consecución de tal propósito. En este sentido, sanciones como las interdictivas bien pueden cumplir dicha misión. Lo esencial es procurar disuadir a las empresas "lícitas" a que trabajen en conjunto con entes criminales.

\section{La confiscación}

Como se ha destacado suficientemente, si se está frente a una criminalidad cuyo propósito fundamental es el lucro da carácter ilícito, debe disponerse de

\footnotetext{
100 Marinuccl; Dolcini, Manuale, cit. nota n. 77, pp. 410-411.

${ }^{101}$ Así lo entienden MarinuCCI; DolCINI, Manuale, cit. nota n. 77, p. 408, quienes agregan: "El problema de la configuración de un concurso de personas en los delitos asociativos se advierte, sobre todo, en relación a lo obrado por algunas categorías de profesionales (abogados, magistrados, empresarios) que supone una objetiva facilitación de las actividades de las asociaciones criminales. Para una correcta solución del problema es decisivo distinguir entre conductas que se comprenden en el ejercicio de las facultades o de los deberes inherentes a aquellas diversas profesiones y conductas que, en cambio, están fuera. Al respecto, en doctrina oportunamente se ha avanzado en propuestas de reformas legislativas, que contengan la explícita enunciación del criterio distintivo".

102 Corvi, "Nuove risposte", cit. nota n. 51, pp. 369-370.
} 
herramientas dirigidas a la ablación de aquellos beneficios económicos que ha obtenido la empresa criminal ${ }^{103}$. Con ello se pretenden perseguir dos objetivos muy claros: el primero y más inmediato, limitar e incapacitar económicamente a la organización, dificultando con ello el desarrollo de sus actividades criminales; el segundo y más amplio, impedir que las organizaciones criminales se infiltren en la economía lícita y de este modo, en la vida política del país ${ }^{104}$. Este segundo propósito puede entenderse, incluso, desde la perspectiva de la seguridad y el orden público de un Estado, pues en la medida en que la criminalidad organizada se infiltra en la economía lícita, adquiriendo poder, puede alterar las reglas del mercado y generar inestabilidad en la convivencia democrática. Supra se destacó los evidentes riesgos de corrupción que se pueden presentar y con ello resquebrajar las bases de un Estado de Derecho.

Considerando, pues, que la criminalidad organizada trabaja con la lógica empresarial y disfrutando del sistema capitalista, es elemental pensar que una de las herramientas a emplear en su contra debe tener un carácter patrimonial ${ }^{105}$. Pues bien, entre estas medidas se encuentra la confiscación, que como se verá es de amplia utilización en el sistema italiano.

Los instrumentos internacionales también contemplan la confiscación, instando a los Estados para que la introduzcan o, en su caso, la adecuen a las nuevas exigencias que impone enfrentar una criminalidad de esta naturaleza. Es así, que la Convención OCDE sobre la lucha a la corrupción de los funcionarios públicos extranjeros en las operaciones económicas internacionales de 1997 en su art. 3 establece que: "3. Cada Parte tomará las medidas necesarias para que el instrumento y el producto del cohecho de un servidor público extranjero o activos de un valor equivalente al de ese producto puedan ser

\footnotetext{
${ }^{103}$ Un examen de la criminalidad organizada conforme al análisis económico del derecho, MANGIONE, Angelo, "Law \& Economics" e diritto penale: paradigma a confronto nell'analisi delle politiche di contrasto alla criminalità organizzata", en MAUGERI, Anna María (Edit.), Le sanzioni patrimoniali come moderno strumento di lotta contro il crimime: reciproco riconoscimento e prospettive di armonizzazione, Giuffrè, Milán, 2008, pp. 147 y ss.

${ }^{104}$ MAUGERI, Anna Maria, "Relazione introduttiva. I modelli de sanzione patrimoniale nel diritto comparato", en MAUGERI, Anna Maria (Edit.), Le sanzioni patrimoniali come moderno strumento di lotta contro il crimime: reciproco riconoscimento e prospettive di armonizzazione, Giuffrè, Milán, 2008, pp. 3-4; Gialanella, Antonio, "Diritto penale e contrasto di prevenzione alle richezze di mafia: utilitarismo 'relativistico' e 'ragionevalezza' garanstista", en PatalANo, Vincenzo (Edit.), Nuove strategie per la lotta al crimine organizzato transnazionale, Giappichelli, Turín, 2003, pp. 193 y ss.

105 Fornarı, Luigi, Criminalità del profitto e tecniche sanzionatorie. Confisca e sanzione pecuniarie nel diritto penale "moderno", Cedam, Padua, 1997, pp. 5 y ss.; MANGIONE, Angelo, La misura di prevenzione patrimoniale fra dogmatica e politica criminale, Cedam, Padua, 2001, pp. 457 y ss.; ALfonso, Roberto, "I problemi e le prospettive del sequestro e della confisca dei patrimoni mafiosi", en Parano, Carola; Centonze, Alessandro (Edit.), L'attività di contrasto alla criminalità organizzata, Giuffrè, Milán, 2005, pp. 207-208.
} 
objeto de embargo y decomiso o sean aplicables sanciones monetarias de efectos comparables.". Por su parte la Convención de Palermo, a la que tantas veces se ha hecho referencia, regula detalladamente en los arts. 12, 13 y 14 la confiscación ${ }^{106}$. Por último, también en el ámbito de la Unión Europea se han dictado normas en esta dirección. Es así, que la Decisión Marco 2005/212/JAI se refiere al decomiso de los productos, instrumentos y bienes relacionados con el delito ${ }^{107}$ y la Decisión Marco 2006/783/JAI al reconocimiento mutuo de las resoluciones sobre decomiso ${ }^{108}$. Precisamente, en la propia motivación de la primera de las indicadas se señala la necesidad de introducir instrumentos de esta naturaleza en el entendido que es un medio eficaz para combatir la criminalidad organizada ${ }^{109}$.

El ordenamiento italiano contempla diversas formas de confiscación, reguladas de manera dispersa en numerosas leyes, además de lo que dispone el propio Código penal. Lo anterior ha generado particulares dificultades en su interpretación y aplicación, pues no son pocos los casos en que se superponen. A lo anterior, debe agregarse los continuos pronunciamientos de las Sesiones Unidas de la Corte de Casación procurando ofrecer algo de luz a esta materia, especialmente engorrosa ${ }^{110}$. Por tal motivo y considerando que el propósito

${ }^{106}$ Alfonso, Roberto, "Confisca e sequestro",en Rosı, Elisabetta (Edit.), Criminalità organizzata transnazionale e sistema penale italiano, Ipsoa, Milán, 2007, pp. 223 y ss.; Grasso, Giovanni, "Profili problematici delle nuove forme di confisca", en MAUGERI, Anna Maria (Edit.), Le sanzioni patrimoniali come moderno strumento di lotta contro il crimime: reciproco riconoscimento e prospettive di armonizzazione, Giuffrè, Milán, 2008, pp. 130 y ss.

107 Ver En: http://eur-lex.europa.eu/LexUriServ/LexUriServ.do?uri=OJ:L:2006:328:0059:0078:ES:PDF [visitado el 21/06/2010].

${ }^{108}$ Ver En: http://eur-lex.europa.eu/LexUriServ/LexUriServ.do?uri=OJ:L:2006:328:0059:0078:ES:PDF [visitado el 21/06/2010].

109 “7. La motivación principal de la delincuencia organizada es la obtención de beneficios económicos. Por consiguiente, todo intento de prevenir y combatir esta delincuencia debe centrarse, para ser eficaz, en el seguimiento, el embargo preventivo, la incautación y el decomiso de los productos del delito. No basta simplemente con garantizar el reconocimiento mutuo dentro de la Unión Europea de medidas legales temporales como el embargo preventivo y la incautación; el control efectivo de la delincuencia económica también exige el reconocimiento mutuo de las resoluciones de decomiso de los productos del delito". Cfr. AlesSANDRI, Alberto. "Criminalità economica e confisca del profitto", en Dolcinı, Emilio; Pallero, Carlo Enrico (Edits.), Studi in onore di Giorgio Marinucci, T. III, Giuffrè, Milán, 2006, pp. 2114-2115; Iuzzouıno, Gabriele, "L'armonizzazione della confisca", en VV.AA., Diritto penale europeo e ordinamento italiano, Giuffrè, Milán, 2006, pp. 353 y ss.; MAUGERI, Anna Maria, "La lotta contro l'accumulazione di patrimoni illeciti da parte delle organizzazioni criminali: recenti orientamenti", en Rivista trimestrale di diritto penale dell'economia, 2007, pp. 572 y ss.

110 Así se aprecia en Alfonso, Roberto, "La confisca penale fra disposizioni codicistiche e legi speciali: esigenze di coordinamento normativo e prospettive di riforma", en MAUGERI, Anna Maria (Edit.), Le sanzioni patrimoniali come moderno strumento di lotta contro il crimime: reciproco riconoscimento e prospettive di armonizzazione, Giuffrè, Milán, 2008, p. 234; MocciA, Sergio, "La confisca quale mezzo 
esencial de este trabajo es exponer las medidas que Italia ha dispuesto en materia de criminalidad organizada, me limitaré a dar a conocer cuáles son las formas de confiscación y su alcance.

Cuatro son las formas de confiscación que se conocen en el Derecho penal italiano: a) confiscación "clásica" del art. 240 del Código penal; b) confiscación por equivalencia-confisca per equivalente-; c) confiscación ampliada-confisca allargata-; d) confiscación como medida de prevención -confisca come misura di prevenzione-.

\subsection{Confiscación "Clásica"}

El Código penal italiano la regula en el art. 240 y la concibe como una medida de seguridad patrimonial. Precisamente, aquí surge la primera controversia, ¿cuál es su naturaleza jurídica? Pues para parte de la doctrina, más que una medida de seguridad es una pena, ya que está completamente desvinculada a la peligrosidad social del condenado, como sí sucede con todas las otras medidas de seguridad. Sin embargo, para gran parte de la doctrina italiana esta hipótesis de confiscación sí conformaría una medida de seguridad, pues su finalidad es la peligrosidad de la cosa. A fin de prevenir nuevos delitos se expropian aquellas cosas que provienen del delito y que pueden incentivar a la comisión de nuevos hechos delictivos ${ }^{111}$. La discusión tiene especial interés, por cuanto la praxis jurisprudencial ha aplicado retroactivamente la confiscación al entenderla como medida de seguridad conforme al art. 200 del Código Penal ${ }^{112}$.

La confiscación del art. 240 puede ser facultativa u obligatoria. En términos generales, la facultativa se aplica en caso de condena y puede recaer sobre aquellas cosas que sirvieron o fueron destinadas a cometer el delito y de las cosas que son su producto o el provecho. Como se aprecia, no difiere mayormente de lo que se ha entendido tradicionalmente por comiso o confiscación. Lo interesante es resaltar cuáles han sido las nuevas orientaciones jurisprudenciales. En este sentido, particular atención debe prestarse respecto del alcance del término "provecho", que tradicionalmente se ha entendido como aquellas cosas que representan la utilidad económica directa o indirectamente obtenida con la comisión del delito. Así, el dinero robado o aquel obtenido por la venta de las cosas objeto del hurto o, incluso, con la venta de drogas ${ }^{113}$. Pues bien,

di contrasto alla criminalità organizzata", en PATALANo, Vincenzo (Edit.), Nuove strategie per la lotta al crimine organizzato transnazionale, Giappichelli, Turín, 2003, pp. 349 y ss.

${ }^{111}$ Cfr. por todos, Dolcinl; MarinucCl, Codice Penale commentato, T. I, cit. nota n. 99, p. 1804.

$112 \mathrm{Al}$ respecto, Grasso, “Profili problematici”, cit. nota n. 106, pp. 134 y ss.

${ }^{113}$ MarinucCl; Dolcinl, Manuale, cit. nota n. 77, p. 650. 
la actual orientación de los tribunales también ha comprendido las utilidades indirectamente derivadas del empleo del provecho del delito. Por ejemplo, el canon obtenido por el departamento adquirido con el dinero producto del delito; los intereses bancarios provenientes del dinero robado; el departamento adquirido con la permuta del inmueble adquirido con el dinero robado.

Precisamente en las Sesiones unidas de la Corte de Casación, sentencia № 10280 de 25 de octubre de 2007, se señala expresamente que se sigue una interpretación extensiva"14. Es así que "cualquier transformación que el dinero ilícitamente obtenido sufra por efecto de la inversión del mismo debe ser considerada provecho del delito cuando sea causalmente vinculable al delito mismo y al provecho inmediato -el dinero- conseguido y sea subjetivamente atribuible al autor del delito que ha querido tal transformación".

Es la propia Corte de Casación, en la sentencia en cuestión, la que reconoce que esta interpretación de la confiscación asume funciones disuasivas similares a la llamada confiscación por equivalencia-se pueden confiscar bienes de valor equivalente, aunque no tengan un vínculo con el delito- ${ }^{115}$. Es decir, hacer ver al delincuente que ya no basta con transformar o invertir el bien. Probándose los vínculos causales objetivos y subjetivos puede imponerse la confiscación que se examina. Las dificultades que se pueden presentar se refieren a aquellos casos que las inversiones tienen lugar en actividades lícitas y no pueda acreditarse si el enriquecimiento se debe a dicha inversión o, simplemente, a adecuados manejos empresariales ${ }^{116}$. Frente a ello, es que puede recurrirse a las otras formas de confiscación.

Con respecto a la confiscación obligatoria, el art. 240 del Código penal contempla dos hipótesis: a) "las cosas que constituyen el precio del delito", esto es, el dinero u otra utilidad económica dirigidas a instigar o determinar a un sujeto a cometer el delito; b) las cosas "cuya fabricación, uso, porte, tenencia o enajenación está prevista por la ley como delito", como sucede, por

\footnotetext{
${ }^{114}$ Ver sentencia en Diritto penale e processo, 10, 2008, pp. 1295 y ss. Al respecto, MAUGERI, "Relazione introduttiva", cit. nota n. 104, p. 11.

115 Sentencia citada № 114, p. 1299: "En efecto, el legislador siempre más consciente que para combatir el crimen es necesario eliminar la posibilidad para el agente de asegurarse el provecho del delito, desde el momento en que el objeto de gran parte de los más graves delitos es precisamente el enriquecimiento, ha pretendido construir todo un sistema que permita en primer lugar la confiscación del provecho inmediato, para después, siempre conforme al art. 240 c.p. la confiscación del Ilamado provecho indirecto o mediato. Es decir, de los bienes que sean causalmente reconducibles a la actividad del reo. En fin, para aquello que concierne a los delitos contra la administración pública, la confiscación por equivalencia de acuerdo al art. 322 ter c.p.".

${ }^{116}$ Cfr. LunGHINI, Giacomo; Musso, Luca, "La confisca nel diritto penale", Il corriere del Merito 2, 2009, p. 10; Fornari, Criminalità del profitto, cit. nota n. 105, p. 114.
} 
ejemplo, con las armas de guerra, productos alimentarios confeccionados con componentes prohibidos por ley ${ }^{117}$.

Con el correr de los años se han ido ampliado las hipótesis de confiscación obligatoria. Al respecto y para efectos de este trabajo, se puede citar la contemplada en el art. 416 bis inciso $7^{\circ}$ del Código penal: serán objeto de confiscación todas aquellas cosas que sirvieron o fueron destinadas a cometer el delito y de las cosas que constituyen el precio, el producto, el provecho o que surgen de su realización. Lo que se pretende es privar al condenado por asociación de tipo mafioso de todos aquellos instrumentos que permiten llevar a cabo los fines de la agrupación, como asimismo, todo aquello que ha sido obtenido realizando el programa criminal de la asociación ${ }^{118}$.

Cabe destacar que esta forma de confiscación se inscribe en una estrategia más amplia en contra de las actividades económicas de la criminalidad organizada. En efecto, a esta medida se debe agregar la confiscación ampliada y la confiscación como medida de prevención -analizadas infra-. Por lo anterior, no sólo pueden ser objeto de la confiscación aquellos bienes que tengan vinculación con el delito, sino también aquellos que provienen del delito y que se hayan empleado para invertirlos o se hayan empleado con fines de ocultamiento. Asimismo, podrán confiscarse los bienes que parecen no corresponder con los réditos declarados por el condenado ${ }^{119}$.

Tratándose de las asociaciones terroristas, conforme lo dispone el art. 270 bis inciso $4^{\circ}$, también procede la confiscación obligatoria. Se aplica en los mismos términos recién expuestos, esto es, serán objeto de confiscación todas aquellas cosas que sirvieron o fueron destinadas a cometer el delito y de las cosas que constituyen el precio, el producto, el provecho que surgen de su realización.

\subsection{Confiscación por equivalencia}

Dadas las limitaciones que presenta la llamada confiscación "clásica" para enfrentar determinadas formas de criminalidad como la aquí examinada, es que se ha introducido la confisca per equivalente-también llamada confisca di valore-. Como se destacó, poco puede hacer la "clásica" cuando el provecho del delito ha sido reinvertido o reutilizado, tornando difuso y difícil de acreditar el requisito esencial de la peligrosidad de la cosa, al no poder precisarse cuáles han sido los bienes que conforman el provecho inicial. Por tal motivo

\footnotetext{
117 MarinucCl; Dolcini, Manuale, cit. nota n. 77, p. 651.

118 Dolcinl; Marinucci, Codice Penale commentato, T. II, cit. nota n. 99, pp. 3128 y ss.

${ }^{119}$ Así, LunGHINl; Musso, "La confisca", cit. nota n. 116, p. 16.
} 
es que numerosas legislaciones han introducido esta forma de confiscación, respondiendo a lo dispuesto en tratados internacionales, como por ejemplo, la Convención OCDE o la Convención de Palermo ${ }^{120}$.

Se aplica subsidiariamente a la confiscación "clásica", cuando resulte particularmente complejo poder precisar los bienes que provienen del delito. Es posible dirigirse a otros bienes de valor equivalente a la medida del provecho o del precio del delito, sin atender si su origen es o no lícito ${ }^{121}$. Cabe destacar que en el ordenamiento italiano no se contempla una hipótesis general de confiscación por equivalencia, sino que se dispone para determinados delitos en particular - por tanto, conforme al principio de taxatividad opera excepcionalmente-. Es así, que los supuestos más importantes se encuentran en relación a los delitos contra la Administración pública -materializando así lo dispuesto en la citada Convención OCDE-, que es un área especialmente fértil para la corrupción. Al respecto, el art. 322 ter del Código Penal regula cómo y bajo qué circunstancias se aplica la confiscación por equivalencia en estos delitos ${ }^{122}$.

Dada la particular estructura que presenta esta forma de confiscación es que se ha ido extendiendo a otros delitos. Entre otros, pueden citarse los delitos de pornografía infantil -art. 600 septies del Código Penal-; blanqueo de capitales -art. 648 quáter del Código Penal-123. Así también, respecto de los delitos societarios se contempla en el art. 2641 del Código civil ${ }^{124}$. En materia de intermediación financiera, se contempla para los delitos de información privilegiada y manipulación del mercado la confiscación por equivalencia como subsidiaria de la confiscación "clásica" -art. 187 sexies del Decreto Legislativo No 58 de 1998-.

En relación a la responsabilidad de las personas jurídicas -expuesta precedentemente- el art. 9 contempla la confiscación dentro de un conjunto de sanciones a aplicar. Su regulación se halla en el art. 19 del Decreto Legislativo

\footnotetext{
120 MaUgerl, "La lotta contro l'accumulazione", cit. nota n. 109, p. 502; MarRa, Gabriele, "Contrasto e prevenzione della corruzione transnazionale", en Rosı, Elisabetta (Edit.), Criminalità organizzata transnazionale e sistema penale italiano, Ipsoa, Milán, 2007, pp. 128 y ss.

121 LUnGHINl; Musso, "La confisca", cit. nota n. 116, p. 29; Fornarl, Criminalità del profitto, cit. nota n. 105, pp. 105 y ss.; MarinUCCI; DolCINI, Manuale, cit. nota n. 77, p. 652.

122 Амато, Giuseppe, "Sì alla confisca «per equivalente» del profitto dopo la condanna per reati di corruzione", Guida al Diritto 47, 2005, pp. 52 y ss.

${ }^{123}$ BRUNO, Lino Giorgio, "Il contrasto all'illecita accumulazione della ricchezza: dal sistema antiriciclaggio alle forme di confisca", en Diritto penale e processo, 3, 2009, pp. 351 y ss.

${ }^{124}$ Sciumbata, Gabriele, I reati societari. $2^{a}$ Edición, Giuffrè, Milán, 2008, pp. 156-157; Dolcinl; MarINucCl, Codice Penale commentato, T. II, cit. nota n. 99, pp. 5219-5220.
} 
№ 231, disponiendo que la confiscación por equivalencia se impone de forma subsidiaria en caso de no ser posible aplicar la confiscación "clásica"125.

En cuanto a su naturaleza y a diferencia de lo que ocurre con la confiscación "clásica", no se trata de una medida de seguridad patrimonial sino derechamente de una sanción. A dicha conclusión se ha llegado no sólo porque algunas disposiciones la consideran como tal -así, el citado art. 19 respecto de la responsabilidad del ente-, sino que además, como lo han reconocido los tribunales ${ }^{126}$, no se aprecia -como sí acontece con la "clásica"- que los bienes confiscados sean peligrosos; es decir, no se configura una relación directa e instrumental entre los bienes y el delito. Por el contrario, mediante su imposición se pretende restablecer una situación económica que ha sido modificada indebidamente a favor del condenado, a través de un sacrificio de carácter patrimonial. Por tanto, al tratarse de una institución que tiene un carácter puramente aflictivo y no de medida de seguridad, no puede a su vez aplicarse retroactivamente ${ }^{127}$.

\subsection{Confiscación ampliada}

Se trata de una medida dispuesta fundamentalmente para enfrentar a la criminalidad organizada. En este caso, la confiscación ya no recae sobre los bienes que provienen del delito o respecto de aquellos que tienen un valor equivalente, sino que se aplica sobre bienes que se presumen provienen de actividades ilícitas. Ya no es relevante que estos bienes se identifiquen con el delito por el cual es condenado, sino que se impone cuando se estima que son bienes de un presumible origen ilícito, al no corresponder, por ser desproporcionado, al rédito o actividades económicas desempeñadas por el

\footnotetext{
125 MAUGERI, Anna Maria, Le moderne sanzioni patromoniali tra funzionalità e garantismo, Giuffrè, Milán, 2001, pp. 153 y ss.; MAugerl, Anna Maria, "Relazione introduttiva", cit. nota n. 104, pp. 15 y ss.; Vizzardi, Matteo, "Art. 19", en Presutti, Adonella; Bernasconi, Alessandro; Fiorio, Carlo, La responsabilità degli enti. Commento articolo per articolo al D. Legisl. 8 giugno 2001 NN$^{\circ} 231$, Cedam, Padua, 2008, pp. 228 y ss.; FornARI, Luigi, "La confisca del profitto nei confronti dell'ente responsabile di corruzione: profili problematici", en Rivista trimestrale di diritto penale dell'economia, 2005, pp. 63 y ss.; AlesSANDRI, "Criminalità economica", cit. nota n. 109, pp. 2130 y ss.

${ }^{126}$ Entre otras, sentencia de la Corte de Casación penal, sez. III, de 24 de septiembre de 2008, № 39172 que señala: "La confisca per equivalente, infatti, viene ad assolvere ad una funzione sostanzialmente ripristinatoria della situazione economica, modificata in favore del reo dalla commissione del fatto illecito, mediante l'imposizione di un sacrificio patrimoniale di corrispondente valore a carico del responsabile ed è, pertanto, connotata dal carattere afflittivo e da un rapporto consequenziale alla commissione del reato proprio della sanzione penale, mentre esula dalla stessa qualsiasi funzione di prevenzione che costituisce la principale finalità delle misure di sicurezza"; Corte Constitucional,

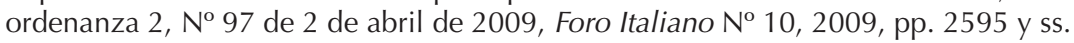

127 MarinucCl; DolcinI, Manuale, cit. nota n. 77, p. 652; LunGHINI; Musso, "La confisca", cit. nota n. 116, p. 34.
} 
condenado. Se habla más bien de confiscación al patrimonio, más que confiscación de bienes ${ }^{128}$.

La confiscación ampliada se introdujo por el Decreto Ley $N^{\circ} 306$ de 8 de junio de 1992, convertido en Ley $N^{\circ} 356$ de 7 de agosto de $1992^{129}$. El art. 12 sexies señala que en caso de condena o de aplicación de una sentencia negociada - patteggiamento- por determinados delitos se debe siempre disponer la confiscación del dinero, bienes o utilidades que el condenado no pueda justificar su proveniencia y que resulte desproporcionado con su rédito o actividad económica. Entre los delitos donde cabe su aplicación, se pueden citar los siguientes -algunos incorporados posteriormente-: delitos contra la administración pública ${ }^{130}$; asociación de tipo mafioso; terrorismo o subversión; trata de personas; blanqueo de capitales, tráfico ilícito de estupefacientes.

Son varios los aspectos que Ilaman la atención. Por una parte, la carga de la prueba recae sobre el condenado, por cuanto se parte de una presunción de que al haber desproporción entre los bienes y el rédito tendrían, por tanto, un origen ilícito. Por otra parte, al no haber una previa determinación cuantitativa de lo confiscable -como sí se exige en los dos casos citados anteriormente-podría recaer sobre todo el patrimonio del condenado; es decir, la confiscación puede llegar a ser más alta que el provecho que se determinó en la condena.

Por lo anterior, se puede presentar la situación paradojal de que un bien que puede confiscarse por equivalencia, no lo sea a través de la ampliada. Es el caso de un bien heredado lícitamente que resulta desproporcionado con su actual rédito ${ }^{131}$. En todo caso, la ley dispone que en caso de no poder aplicarse la confiscación ampliada se imponga la confiscación por equivalencia.

Para estos casos no es relevante cuándo fueron adquiridos los bienes, pudiendo haber ingresado en el patrimonio del condenado mucho antes de haber

\footnotetext{
${ }^{128}$ LUNGHINI; Musso, "La confisca", cit. nota n. 116, p. 43.

129 FORNASARI, Gabriele, "Strategie sanzionatorie e lotta alla criminalità organizzata in Germania e in Italia", Rivista trimestrale di diritto penale dell'economia, 1994, pp. 762 y ss.; PотеттI, Domenico, "Riflessioni in tema di confisca di cui alla legge 501/1994", en Cassazione Penale, 1995, pp. 1689 y ss.; MAUGERI, Anna Maria, "La sanzione patrimoniale fra garanzie e efficienza", Rivista trimestrale di diritto penale dell'economia, 1996, pp. 832 y ss.; FornaRI, Criminalità del profitto, cit. nota n. 105, pp. 63 y ss.; Alfonso, "La confisca penale", cit. nota n. 110, pp. 234 y ss.; Alfonso, Roberto, "I problemi", cit. nota n. 105, pp. 221 y ss.; Moccia, "La confisca", cit. nota n. 110, pp. 358 y ss.

${ }_{130}$ Acquarol, Roberto, "L'estensione dell'art. 12 sexies I. No 356/1992 ai reati contro la Pubblica Amministrazione", Diritto penale e processo 2, 2008, pp. 251 y ss. examina las críticas que ha generado la incorporación de este delito, considerando que la idea original era disponer la confiscación ampliada respecto a la criminalidad organizada; MAUGERI, "La lotta contro l'accumulazione", cit. nota n. 109, pp. 497 y ss.

${ }^{131}$ Señalado por LuNGHINl; Musso, "La confisca", cit. nota n. 116, p. 44.
} 
cometido el delito o incluso después. Lo determinante, como se ha dicho, es la presunción acerca de la ilícita acumulación patrimonial, que sólo puede desvirtuarse a través de la acreditación de la licitud del origen de los bienes ${ }^{132}$.

Un problema particular se presenta en relación a su naturaleza, pues la jurisprudencia ha sostenido que se trataría de una medida de seguridad patrimonial, por tanto, de aplicación retroactiva ${ }^{133}$. En efecto, se ha sostenido que la suma de los bienes de valor desproporcionado es una realidad actual, de la que se deriva una situación de peligrosidad presente, no siendo relevante el que hayan sido adquiridos con fecha anterior o posterior al delito. Se trataría, pues, de una medida de seguridad atípica que cumpliría una función disuasiva como, asimismo, una medida de prevención antimafia ${ }^{134}$. Para la doctrina no deja de Ilamar la atención tal encuadramiento, en circunstancia que acá, al igual que en la equivalente, no es exigible que exista una relación entre los bienes y el delito. Amén, de ser impuesta a través de una sentencia de condena o, en su caso, por sentencia negociada ${ }^{135}$.

\subsection{Confiscación como medida de prevención}

Se introdujo en el ordenamiento italiano por el art. 14 de la Ley $\mathrm{N}^{\circ} 646$ de 13 de septiembre de 1982, que agregó el art. 2 ter a la Ley No 575 de 31 de mayo de 1965 que dispone de medidas en contra de la mafia ${ }^{136}$. En consecuencia, tiene una clara dirección de lucha contra la criminalidad organizada. Si bien tiene similitudes con la confiscación ampliada, en cuanto recae sobre

\footnotetext{
132 Sentencia de la Corte de CASACIÓn Penal, sez. II, de 26 de febrero de 2009, № 10549; sentencia de Corte de Casación penal, sez. I, de 18 de febrero de 2009, № 10756.

${ }^{133}$ Grasso, "Profili problematici", cit. nota n. 106, pp. 134 y ss.

${ }^{134}$ Sentencia de la Corte de Casación penal, sez. un. de 19 de enero de 2004, № 920; Sentencia de la Corte de Casación penal, sez. un. de 19 de julio de 2001, № 29022; Sentencia de la Corte de Casación penal, sez. un. de 27 de marzo de 2008, № 26654: "Sulla base della tracciata evoluzione normativa, appare assai arduo, oggi, catalogare l'istituto della confisca nel rigido schema della misura di sicurezza, essendo agevole per esempio riconoscere, in quella di valore, i tratti distintivi di una vera e propria sanzione e, in quella "speciale", una natura ambigua, sospesa tra funzione specialpreventiva e vero e proprio intento punitivo".

135 LUNGHINI; Musso, "La confisca", cit. nota n. 116, pp. 45; sobre los pronunciamientos generalmente favorables de la Corte Europea de los Derechos Humanos acerca de la confiscación ampliada, MAUGERI, Anna Maria, "La riforma delle sanzioni patrimoniali: verso un'actio in rem?", en MAZZA, Oliviero; VIGANÒ, Francesco (Edits.), Misure urgenti in materia di sicurezza pubblica, Giappichelli, Turín, 2008, pp. 181 y ss.

136 NicASTRO, Guglielmo, "La confisca nella legislazione patrimoniale antimafia", en MAUGERI, Anna Maria (Edit.), Le sanzioni patrimoniali come moderno strumento di lotta contro il crimime: reciproco riconoscimento e prospettive di armonizzazione, Giuffrè, Milán, 2008, pp. 285 y ss.; CASSANO, Francesco, Misure di prevenzione patrimoniali e amministrazione dei beni, Giuffrè, Milán, 1998, pp. 153 y ss.; crítico, Moccia, "La confisca", cit. nota n. 110, pp. 353 y ss.
} 
bienes de valor desproporcionado con respecto al rédito y que no se justifican, la diferencia esencial dice relación con su aplicación. En efecto, en el caso que se examina no se requiere de sentencia de condena, y sólo puede imponerse dentro del procedimiento dirigido a la aplicación de una medida de prevención antimafia -art. 2 Ley $\mathrm{N}^{\circ} 575-$, que pueden consistir en vigilancia especial u obligación de residir en un cierto lugar. Pues bien, el tribunal puede llegar a confiscar cuando habiendo impuesto la medida de prevención y sobre la base de que el sujeto no ha podido justificar la legítima proveniencia de los bienes $\mathrm{o}$, en su caso, se manifiesta una desproporción entre la disponibilidad de determinados bienes y su rédito. Cabe destacar que el tribunal puede, incluso, durante el procedimiento en cuestión -antes de decidirse la aplicación de la medida- secuestrar los mismos bienes cuando existen indicios suficientes que provienen de actividades ilícitas o la disposición de ciertos bienes es desproporcionado a su rédito.

Como se puede apreciar, el mayor problema que enfrenta esta institución dice relación con la prueba. Mientras la confiscación procede cuando no se puede justificar la legítima proveniencia de los bienes, el secuestro se configura cuando hay indicios suficientes. Tal distinción ha llevado a la jurisprudencia ha disponer de estándares probatorios diversos, según sea el momento de la imposición de la medida. Tratándose del secuestro es suficiente que haya una razonable probabilidad acerca de la ilicitud del bien o sobre la desproporción de ciertos bienes con el rédito del sujeto. En cambio, para imponer la confiscación se requiere una demostración en donde concurren requisitos de gravedad, precisión y concordancia ${ }^{137}$.

A fin de evitar que se produzcan determinadas maniobras dirigidas a sustraer bienes que pueden ser objeto del secuestro o de la confiscación, se dispone lo que podría denominarse medida de prevención por equivalencia; es decir, el procedimiento también puede recaer sobre dinero o bienes de valor equivalente ${ }^{138}$.

\section{CONSIDERACIONES FINALES}

Como se ha destacado desde el inicio de este trabajo, las particularidades que hoy presenta la criminalidad organizada imponen a los Estados la obligación de adoptar medidas para enfrentarla. Dentro de éstas, considerando que

\footnotetext{
${ }^{137}$ MAUGERI, "La riforma", cit. nota n. 135, p. 160; MAUGERI, Le moderne sanzioni, cit. n. 125, pp. 839 y Ss.; MollaCe, Francesco, "Le modifiche in tema di normativa antimafia e di repressione delle organizazzioni mafiose", en Amato, Giuseppe; Santoriello, Ciro, Misure urgenti in materia di sicurezza pubblica, Utet, Turín, 2009, p. 176; ForNARı, Criminalità del profitto, cit. nota n. 105, pp. 216 y ss.

138 MAUGerI, "La riforma", cit. nota n. 135, p. 166.
} 
uno de sus propósitos fundamentales es el lucro, se deben comprender las de carácter patrimonial. A través de ellas no sólo se pretende disminuir su poder de actuación, incapacitándola económicamente, sino también impedir que estas organizaciones se infiltren en la economía lícita de un país. Los riesgos son evidentes, pues además de verse afectadas las reglas básicas del mercado -se trata de un competidor carente de toda ética-, se pueden generar serias fisuras en la base democrática de una nación, ya sea a través de la corrupción de los funcionarios públicos o actos de violencia para delimitar territorios de control.

Es indudable que las medidas de carácter económico, como son la confiscación y la responsabilidad de la persona jurídica, deben ir unidas a otras como son las penas privativas de libertad. No se va a discutir aquí su innegable eficacia disuasiva. Ahora bien, para que ello sea así, es preciso delimitar muy claramente los delitos que son manifestación de esta forma de criminalidad. En este sentido, desempeñan un papel de particular relevancia los Ilamados delitos asociativos, pues permiten una eficaz e incisiva intervención de la herramienta punitiva, sin que requiera acreditar la comisión de los delitos que son fines de la asociación. A este respecto, podría explorarse la posibilidad de estructurar un tipo penal que recoja los elementos esenciales de la criminalidad organizada, de manera tal de ir precisando cuál es el objeto principal de persecución. Con la conformación de un tipo de injusto, es posible disponer de penas especialmente altas respecto de quienes la dirigen, permitiendo a su vez distinguir a quien no formando parte de la organización sí colabora con ella ${ }^{139}$.

En materia de investigación -tanto el Ministerio Público como la policía-se debe contar con organismos centralizados y especializados. Es la forma más eficiente para poder enfrentar adecuadamente estas estructuras organizativas de orden criminal, algunas de ellas muy poderosas. Lo anterior permite que en el plano internacional se trabaje coordinadamente, tanto con instituciones policiales como judiciales.

Sin perjuicio de las medidas penales, también es preciso contar con un arsenal de medidas extrapenales que impidan a estas organizaciones ingresar en la actividad económica. Un ejemplo son las disposiciones adoptadas por el legislador italiano en cuanto a impedir la participación en concursos públicos. Por último, no puede dejarse de lado el factor pobreza y marginalidad. No sólo quienes integran las organizaciones criminales lo ven muchas veces como su única salida a su condición, sino que también afecta a quienes son víctimas de éstas. En efecto, quienes son objeto de la trata de personas provienen de

${ }^{139}$ Así también, ZúÑIGA, Criminalidad organizada, cit. nota n. 6, pp. 280-281. 
sociedades pobres o fuertemente excluyentes, que impiden toda forma de integración social.

\section{BibLIOGRAFíA}

ACQUAROLI, Roberto, "L'estensione dell'art. 12 sexies I. № 356/1992 ai reati contro la Pubblica Amministrazione", Diritto penale e processo 2, 2008.

Aldrovand, Paolo, "I «modeli di organizzazione e di gestione» nel D. Lgs. 8 giugno 2001, $N^{\circ}$ 231: aspetti problematici dell' «ingerenza penalistica» nel "governo» delle società", Rivista trimestrale di diritto penale dell'economia, 2007.

AlEO, Salvatore, "Criminalità transnazionale e definizione della criminalità organizzata: il requisito dell'organizzazione", en Patalano, Vincenzo (Edit.), Nuove strategie per la lotta al crimine organizzato transnazionale, Giappichelli, Turín, 2003.

, "Associazione, organizzazione, concorso esterno", en PARANO, Carola; CENTONZE, Alessandro (Edits.), L'attività di contrasto alla criminalità organizzata, Giuffrè, Milán, 2005.

AleSSANDRI, Alberto, "Criminalità economica e confisca del profitto", en DolCINI, Emilio; Paliero, Carlo Enrico (Edits.), Studi in onore di Giorgio Marinucci, T. III, Giuffrè, Milán, 2006.

"Note penalistiche sulla nuova responsabilità delle persone giuridi-

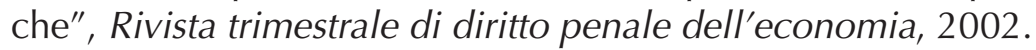

"Riflessioni penalistiche sulla nuova disciplina", en VV.AA., La responsabilità ammnistrativa degli enti, Ipsoa, Milán, 2002.

Alfonso, Roberto, "Confisca e sequestro", en Rosı, Elisabetta (Edit.), Criminalità organizzata transnazionale e sistema penale italiano, Ipsoa, Milán, 2007.

"I problemi e le prospettive del sequestro e della confisca dei patrimoni mafiosi", en PARANO, Carola; Centonze, Alessandro (Edits.), L'attività di contrasto alla criminalità organizzata, Giuffrè, Milán, 2005.

, "La confisca penale fra disposizioni codicistiche e legi speciali: esigenze di coordinamento normativo e prospettive di riforma", en MAUGERI, Anna Maria (Edit.), Le sanzioni patrimoniali come moderno strumento di lotta contro il crimime: reciproco riconoscimento e prospettive di armonizzazione, Giuffrè, Milán, 2008.

AMARELLI, Giuseppe, "La responsabilità delle persone giuridiche e la repressione della criminalità organizzata transnazionale", en PATALANO, Vincenzo (Edit.), Nuove strategie per la lotta al crimine organizzato transnazionale, Giappichelli, Turín, 2003. 
АмAто, Giuseppe, "Sì alla confisca "per equivalente» del profitto dopo la condanna per reati di corruzione", Guida al Diritto 47, 2005.

Amato, Giuseppe; Santoriello, Ciro, Misure urgenti in materia di sicurezza pubblica, Utet, Turín, 2009.

Angelini, Marco, "Art. 9", en Presutti, Adonella; Bernasconi, Alessandro; Fiorio, Carlo, La responsabilità degli enti. Commento articolo per articolo al D. Legisl. 8 giugno 2001 No 231, Cedam, Padua, 2008.

Arena, Maurizio; CASSANO, Giuseppe, La responsabilità da reato degli enti collettivi, Giuffrè, Milán, 2007.

Astrologo, Annamaria, "Prime riflessioni sulla definizione di reato transnazionale nella L. № 146/2006", Cassazione Penale 4, 2007.

BARATTA, Alessandro, "Mafia: rapporti tra modelli criminologici e scelte di politica criminale", en MocciA, Sergio (Edit.), Criminalità organizzata e risposte ordinamentali, Edizioni Scientifiche Italiane, Nápoles, 1999.

BARTOLOMUCCI, Sandro, Corporate governance e responsabilità delle persone giuridiche, Ipsoa, Milán, 2004.

BASSIOUNI, Cherif M., "Strumenti giuridici peri il contrasto del terrorismo internazionale: un'analisi di carattere politico", en BAssıounI, Cherif M. (Edit.), La cooperazione internazionale per la prevenzione e la repressione della criminalitá organizata e del terrorismo, Giuffrè, Milán, 2005.

BAuCCIO, Luca, L'accertamento del fatto reato di terrorismo internazionale. Aspetti teorici e pratici, Giuffrè, Milán, 2005.

BeCCHI, Ada/Rey, Guido M., L'economia criminale, Laterza, Bari, 1994.

Belluta, Hervé, "Cybercrime e responsabilità degli enti", en LuPÁRIA, Luca (Edit.), Sistema penale e criminalità informatica, Giuffrè, Milán, 2009.

Bernasconi, Alessandro, "Art. 5", en Presutti, Adonella; Bernasconi, Alessandro; Fıorıo, Carlo, La responsabilità degli enti. Commento articolo per articolo al D. Legisl. 8 giugno 2001 Nº 231, Cedam, Padua, 2008.

"Art. 6", en Presutti, Adonella; Bernasconi, Alessandro; Fiorio, Carlo, La responsabilità degli enti. Commento articolo per articolo al D. Legisl. 8 giugno 2001 № 231, Cedam, Padua, 2008.

BERNASCONI, Alessandro, La collaborazzione processuale. Incentivi, protezione e strumenti di garanzia a confronto con l'esperienza statunitense, Giuffrè, Milán, 1995.

Bertorotta, Francesco, "Concorso eventuale di persone e reati associativi", Rivista italiana di diritto e procedura penale, 1998.

Bıock, Antón, The Mafia of a Sicilian Village 1860-1960, Basil Blackwell, Oxford, 1974. 
BReNDER, Markus, Die Neuregelung der Verbandstäterschaft im Ordnungswidrigkeitenrecht, Friburgo, 1989.

Brown, Bartram, "Primacy or Complementarity: Reconciling the Jurisdiction of National Courts and International Criminal Tribunals", The Yale Journal of International Law Vol. 23, 1998.

Bruno, Lino Giorgio, "Il contrasto all'illecita accumulazione della ricchezza: dal sistema antiriciclaggio alle forme di confisca", Diritto penale e processo 3, 2009.

CAFERRA, Vito Marino, Il sistema della corruzione. Le ragioni, i soggetti, i luoghi, Laterza, Roma-Bari, 1992.

Cancio Melí, Manuel, "Sentido y límites de los delitos de terrorismo", en Serrano-Piedecasas, José Ramón; Demetrio Crespo, Eduardo (Dirs.), Terrorismo y Estado de Derecho, lustel, Madrid, 2010.

Carneval, Raúl, "Derecho penal como ultima ratio. Hacia una política criminal racional", en Problemas de política criminal y otros estudios, LegalPublishing, Santiago, 2009.

Carneval, Raúl; Fuentes, Hernán, "Informe jurídico sobre la eventual aplicación del delito de asociación ilícita establecido en el art. 16 de la Ley № 20.000", Política Criminal 6, D1, 2008.

Carretero Pérez, Adolfo; Carretero Sánchez, Adolfo, Derecho administrativo

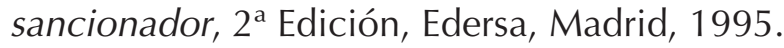

Castaldo, Andrea; Naddeo, Marco, II denaro sporco. Prevenzione e repressione nella lotta al riciclaggio, Cedam, Padua, 2010.

Castellana, A. M., "Diritto penale dell'Unione Europea e principio 'Societas delinquere non potest'", Rivista trimestrale di diritto penale dell'economia, 1996.

CASSANO, Francesco, Misure di prevenzione patrimoniali e amministrazione dei beni, Giuffrè, Milán, 1998.

Cavaliere. Antonio, "Tipicità ed offesa nei reati associativi", en Patalano, Vincenzo (Edit.), Nuove strategie per la lotta al crimine organizzato transnazionale, Giappichelli, Turín, 2003.

CoHen, A. K., "The concept od criminal organization", British Journal of Criminology Vol. 17, 1977.

Corbetta, Stefano; Della Bella, Angela; Gatta, Gian Luigi (Edits.), Sistema penale e "sicurezza pubblica": le riforme del 2009, Ipsoa, Milán, 2009.

Cordero Blanco, Isidoro, El delito de blanqueo de capitales, $2^{a}$ Edición, Aranzadi, Pamplona, 2002. 
CORVI, Angela, "Nuove risposte al crimine organizzato tra diritto penale e sanzioni ammnistrative", en MazzA, Oliviero; VIGANò, Francesco (Edits.), II "pachetto" sicurezza 2009, Giappichelli, Turín, 2009.

D'Amato, Antonio, "Art. 10 I. 16 marzo 2006, No 146", en Presutti, Adonella; BernasConı, Alessandro; FIOrIo, Carlo, La responsabilità degli enti. Commento articolo per articolo al D. Legisl. 8 giugno 2001 NN$^{\circ}$ 231, Cedam, Padua, 2008.

"La cooperazione internazionale nell'esercizio della funzione giurisdizionale. Dalle rogatorie alle squadre investigative comuni in attuazione dei principi del "terzo pilastro" del Tratatto sull'Unione Europea", en PATALANO, Vincenzo (Edit.), Nuove strategie per la lotta al crimine organizzato transnazionale, Giappichelli, Turín, 2003.

De Francesco, Giovannangelo, "Internazionalizzazione del diritto e della politica criminale: verso un equilibrio di molteplici sistemi penali", Diritto penale e processo 1, 2003.

De MAGLIE, Cristina, L'etica e il mercato. La responsabilità penale della società, Giuffrè, Milano, 2002.

, "Principi generali e criteri di attribuzione della responsabilità", Diritto penale e processo 11, 2001.

, "Sanzioni pecuniarie e tecniche di controllo dell'impresa. Crisi e innovazioni nel diritto penale statunitense", Rivista italiana di diritto e procedura penale, 1995.

De Vero, Giancarlo, "Struttura e natura giuridica dell'illecito di ente collettivo dipendente da reato", Rivista italiana di diritto e procedura penale, 2001. Tutela penale dell'ordine pubblico, Giuffrè, Milán, 1988.

De LiguORI, Luigi, "La struttura normativa dell'associazione di tipo mafioso", Cassazione Penale, 1988.

Dı Fiore, Gigi, La camorra e le sue storie, Utet, Turín, 2005.

Di MARTINO, Alberto, "Criminalita organizzata e reato transnazionale, diritto penale nazionale: I'attuazione in Italia della cd. Convenzione di Palermo", Diritto penale e processo 1, 2007.

DolcinI, Emilio; MarinucCl, Giorgio (Edits.), Codice Penale commentato, T. I. $2^{\text {a }}$ Edición, Ipsoa, Milán, 2006.

El ZeidY, Mohamed M., "The principle of complementarity: a new machinery to implement international criminal law", Michigan Journal of International Law Vol. 23, 2001-2002.

Fernández Cruz, José Ángel, "La 'empresa criminal': Los 'delitos de comercio' ilícito como factor de aparición del fenómeno del 'blanqueo de capitales'", Revista de Estudios Criminológicos y Penitenciarios 5, 2002. 
Ferola, Laura, IL riciclaggio dei proventi illeciti nel diritto internazionale, Giuffrè, Milán, 2005.

FerRajol, Luigi, Derecho y razón. Teoría del garantismo penal, Traducción de Andrés Ibáñez, Perfecto y otros, Trotta, Madrid, 1995.

"Il coordinamento delle indagini nei procedimenti per delitti di criminalità organizzata", en Corso, Piermaria; INSOleRA, Gaetano; STORTONI, Luigi (Coords.), Mafia e criminalità organizzata, T. II, Utet, Turín, 1995.

"Sul diritto penale minimo (risposta Giorgio Marinucci e a Emilio Dolcini)", Foro italiano, Parte Quinta, 2000.

FIANDACA, Giovanni, "Criminalità organizzata", L'Indice penale, 1991.

Fiandaca, Giovanni; Musco, Enzo, Diritto penale. Parte generale, $5^{a}$ Edición, Zanichelli Editore, Boloña, 2008.

García Arán, Mercedes (Coord.), Trata de personas y explotación sexual, Comares, Granada, 2006.

Finnaut, Cyrille; Paol, Letizia (Edits.), Organised Crime in Europe. Concepts, Patterns and Control Policies in the European Union and Beyond, Springer, Dordrecht, 2006.

FlorA, Giovanni, "L'attualità del principio 'Societas delinquere non potest'", Rivista trimestrale di diritto penale dell'economia, 1995.

Fornarl, Luigi, Criminalità del profitto e tecniche sanzionatorie. Confisca e sanzione pecuniarie nel diritto penale "moderno", Cedam, Padua, 1997.

, "La confisca del profitto nei confronti dell'ente responsabile di corruzione: profili problematici", Rivista trimestrale di diritto penale dell'economia, 2005.

FORNASARI, Gabriele, "Le strategie di contrasto alla criminalità orgnizzata: aspetti comparatistici nell'esperienza europeo-continentale", en Le strategie di contrasto alla criminalità orgnizzata nella prospettiva di diritto comparato, Cedam, Padua, 2002.

"Strategie sanzionatorie e lotta alla criminalità organizzata in Germania e in Italia", Rivista trimestrale di diritto penale dell'economia, 1994.

GarGanı, Alberto, "Imputazione del reato agli enti collettivi e responsabilità penale dell'intraneo: due piani irrelati?", Diritto penale e processo 9, 2002.

Gialanella, Antonio, "Diritto penale e contrasto di prevenzione alle richezze di mafia: utilitarismo 'relativistico' e 'ragionevalezza' garanstista', en PATALANO, Vincenzo (Edit.), Nuove strategie per la lotta al crimine organizzato transnazionale, Giappichelli, Turín, 2003.

GIASANTI, Alberto, "Marginalità sociale, periferie urbane, racket", en BANDINI, Tullio; Lagazzı, Marco; Marugo, Maria Ida (Edits.), La criminalità organiz- 
zata. Moderne metodologie di ricerca e nuove ipotesi esplicative, Giuffrè, Milán, 1993.

GıavazZı, Stefania, "Le sanzioni interdittive e la publicazione della sentenza penale di condanna", en VV.AA., La responsabilità ammnistrativa degli enti, Ipsoa, Milán, 2002.

Grasso, Giovanni, "Profili problematici delle nuove forme di confisca", en MAUGERI, Anna Maria (Edit.), Le sanzioni patrimoniali come moderno strumento di lotta contro il crimime: reciproco riconoscimento e prospettive di armonizzazione, Giuffrè, Milán, 2008.

Grundi, Milton; Aparna, Nathan, Offshore Business Centres: A world Survey, $8^{a}$ Edición, Sweet \& Maxwell, Londres, 2008.

Gutiérrez Rodríguez, Marceliano, "La delincuencia organizada", en VV.AA., Iurisperitorum digesta, Vol. I, Ediciones Universidad de Salamanca, Salamanca, 2000.

Ilarda, Giovanni; Marullo, Gianfranco (Edits.), Cybercrime: conferenza internazionale. La Convenzione del Consiglio d'Europa sulla Criminalità Informatica, Giuffrè, Milán, 2004.

INSOLERA, Gaetano, "Ancora sul problema del concorso esterno nei delitti associativi", Rivista italiana di diritto e procedura penale, 2008.

Diritto penale e criminalità organizzata, II Mulino, Boloña, 1996.

Iuzzouıno, Gabriele, "L'armonizzazione della confisca", en VV.AA., Diritto penale europeo e ordinamento italiano, Giuffrè, Milán, 2006.

HernánDEZ, Héctor, "La introducción de la responsabilidad penal de las personas jurídicas en Chile", Política Criminal Vol. 9, A5, 2010.

Herzog, Felix, "Straftaten im Internet, Computerkriminalität und die Cybercrime Convention", Política Criminal № 8, D1, 2009.

Huber, Barbara, "La lotta alla corruzione in prospettiva sovranazionale", en Rivista trimestrale di diritto penale dell'economia, 2001.

LaUdatı, Antonio, "Criminalità organizzata e riciclaggio", en Patalano, Vincenzo (Edit.), Nuove strategie per la lotta al crimine organizzato transnazionale, Giappichelli, Turín, 2003.

"I delitti transnazionali. Nuovi modelli di incriminazione e di procedimento all'interno dell'Unione Europea", Diritto penale e processo 4, 2006.

"Il coordinamento delle indagini nel crimine organizzato transnazionale. Il ruolo della Direzione nazionale antimafia alla luce dei coordinamenti in sede europea", en Rosı, Elisabetta (Edit.), Criminalità organizzata transnazionale e sistema penale italiano, Ipsoa, Milán, 2007. 
LEIGH, Leonard, "Possibilities for a European Administrative Penal Law", en SIEBER, Ulrich (Edit.), Europäische Einigung und Europäisches Strafrecht, ColoniaBerlín-Bonn-Munich, 1993.

Lo Monte, Elio, "Ecomafia: il controllo penale tra simbolicità ed effettività", en Patalano, Vincenzo (Edit.), Nuove strategie per la lotta al crimine organizzato transnazionale, Giappichelli, Turín, 2003.

LunGHINI, Giacomo; Musso, Luca, "La confisca nel diritto penale", I/ corriere del Merito 2, 2009.

LUPÁRIA, Luca (Edit.), Sistema penale e criminalità informatica, Giuffrè, Milán, 2009.

MANGiOne, Angelo, "'Law \& Economics' e diritto penale: paradigma a confronto nell'analisi delle politiche di contrasto alla criminalità organizzata", en MAUGERI, Anna Maria (Edit.), Le sanzioni patrimoniali come moderno strumento di lotta contro il crimime: reciproco riconoscimento e prospettive di armonizzazione, Giuffrè, Milán, 2008.

- La misura di prevenzione patrimoniale fra dogmatica e politica criminale, Cedam, Padua, 2001.

MANNA, Adelmo, "L'ammisibilità di un c.d. concorso 'esterno' nei reati associativi, tra esigenze di politica criminale e principio di legalità", Rivista italiana di diritto e procedura penale, 1994.

"La c.d. reponsabilità amministrativa delle persone giuridiche: un primo sguardo d'insieme", Rivista trimestrale di diritto penale dell'economia, 2002.

MARenGHI, Francesco, "La responsabilità delle persone giuridiche nel crimine organizzato transnazionale", en Rosı, Elisabetta (Edit.), Criminalità organizzata transnazionale e sistema penale italiano, Ipsoa, Milán, 2007.

MarinucCl, Giorgio; DolCinI, Emilio, "Diritto penale 'minimo' e nuove forme di criminalità", Rivista italiana di diritto e procedura penale, 1999.

Manuale di Diritto penale. Parte Generale, 3ª Edición, Giuffrè, Milán, 2009.

MaRINUCCI, Giorgio, "La responsabilità penale delle persone giuridiche", Rivista italiana di diritto e procedura penale, 2007.

MARRA, Gabriele, "Contrasto e prevenzione della corruzione transnazionale", en Rosı, Elisabetta (Edit.), Criminalità organizzata transnazionale e sistema penale italiano, Ipsoa, Milán, 2007.

MATus, Jean Pierre, "Informe sobre el proyecto de ley que establece la responsabilidad penal de las personas jurídicas en los delitos de lavados de activos, financiamiento del terrorismo y delitos de cohecho que indica, mensaje № 018-357", Revista lus et Praxis Año 15, № 2, 2009. 
MAUGERI, Anna Maria, "La lotta contro l'accumulazione di patrimoni illeciti da parte delle organizzazioni criminali: recenti orientamenti", Rivista trimestrale di diritto penale dell'economia, 2007.

"La riforma delle sanzioni patrimoniali: verso un'actio in rem?", en Mazza, Oliviero; Vıganò, Francesco (Edits.), Misure urgenti in materia di sicurezza pubblica, Giappichelli, Turín, 2008.

"La sanzione patrimoniale fra garanzie e efficienza", Rivista trimestrale di diritto penale dell'economia, 1996.

Le moderne sanzioni patromoniali tra funzionalità e garantismo, Giuffrè, Milán, 2001.

"Relazione introduttiva. I modelli de sanzione patrimoniale nel diritto comparato", en Le sanzioni patrimoniali come moderno strumento di lotta contro il crimime: reciproco riconoscimento e prospettive di armonizzazione, Giuffrè, Milán, 2008.

MazzA, Oliviero; VIGANÒ, Francesco (Edits.), Misure urgenti in materia di sicurezza pubblica, Giappichelli, Turín, 2008. , II "pachetto" sicurezza 2009, Giappichelli, Turín, 2009.

MiChelINI, Gualtiero; Polımenl, Gioacchino, "Il fenomeno del crimine transnazionale e la Convenzione delle Nazione Unite contro il crimine organizzato transnazionale", en Rosı, Elisabetta (Edit.), Criminalità organizzata transnazionale e sistema penale italiano, Ipsoa, Milán, 2007.

Militello, Vincenzo, "Le strategie di contrasto della criminalità organizzata transnazionale tra esigenze di politica criminale e tutela dei diritti umani", en Parano, Carola; Centonze, Alessandro (Edits.). L'attività di contrasto alla criminalità organizzata, Giuffrè, Milán, 2005.

Militello, Vincenzo; Paol, Letizia; Arnold, Jörg (Edits.), Il crimine orgnizzato come fenomeno internazionale. Forme di manifestazione, prevenzione e repressione in Italia, Germania e Spagna, Ed. Iuscrim, Max Planck Institut, Friburgo, 2000.

MIR PUIG, Santiago, Derecho penal. Parte General, 7ª Edición, Reppertor, Barcelona, 2004.

Mollace, Francesco, "Le modifiche in tema di normativa antimafia e di repressione delle organizazzioni mafiose", en Amato, Giuseppe; Santoriello, Ciro, Misure urgenti in materia di sicurezza pubblica, Utet, Turín, 2009.

Moccia, Sergio, "La confisca quale mezzo di contrasto alla criminalità organizzata", en Patalano, Vincenzo (Edit.), Nuove strategie per la lotta al crimine organizzato transnazionale, Giappichelli, Turín, 2003.

"Prospettive non 'emergenziali' di controllo dei fatti di criminalità organizzata. Aspetti dommatici e di politica criminale", en MocciA, Sergio (Edit.), Criminalità organizzata e risposte ordinamentali, Edizioni Scientifiche Italiane, Nápoles, 1999. 
Moltra, Soumyo D., "Developing Policies for Cybercrime", European Journal of Crime, Criminal Law and Criminal Justice Vol. 13/3, 2005.

MonesI, Carlo (Edit.), I modelli organizativi ex D. Lgs. 231/2001. Etica d'impresa e punibilità degli enti, Giuffrè, Milán, 2005.

Morales García, Óscar (Dir.), Delincuencia informática: problemas de responsabilidad, Cuadernos del Poder Judicial 9, 2002.

Mucciarelli, Francesco, "Le sanzioni interdittive temporanee nel D. Lgs. No 231/2001", en Dolcini, Emilio; Paliero, Carlo Enrico (Edits.), Studi in onore di Giorgio Marinucci, T. III, Giuffrè, Milán, 2006.

MusCatiello, Vincenzo Bruno, "Per una caratterizzazione semantica del concorso esterno", en Rivista italiana di diritto e procedura penale, 1999.

Musco, Enzo, "Los colaboradores de la justicia entre el pentitismo y la calumnia: problemas y perspectivas", Traducción de Sánchez, Virginia, Revista Penal 2, 1998.

Nicastro, Guglielmo, "La confisca nella legislazione patrimoniale antimafia", en MAUGERI, Anna Maria (Edit.), Le sanzioni patrimoniali come moderno strumento di lotta contro il crimime: reciproco riconoscimento e prospettive di armonizzazione, Giuffrè, Milán, 2008.

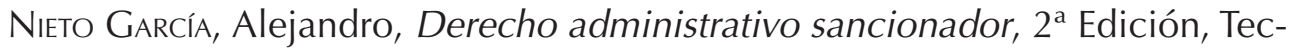
nos, Madrid, 1994.

Nunzl, Alfredo, "La Convenzione delle Nazioni Unite contro la criminalità organizzata transnazionale", en BAssıOUNI, Cherif M. (Edit.), La cooperazione internazionale per la prevenzione e la repressione della criminalitá organizata e del terrorismo, Giuffrè, Milán, 2005.

PADOVANI, Tullio, "Il nome dei principi e il principio dei nomi: la responsabilità "amministrativa" delle persone giuridiche", en De FranCESCO, Giovannangelo (Edit.), La responsabilità degli enti: un nuovo modello di giustizia "punitiva", Giappichelli, Torino, 2004.

Paliero, Carlo Enrico, "La responsabilità delle persone giuridiche: profili generali e criteri di imputazione", en AleSSANDRI, Alberto (Edit.), Il nuovo diritto delle società, Ipsoa, Milán, 2002.

, "La responsabilità penale della persona giuridica nell'ordinamento italiano: profili sistematici", en PALAzZO, Francesco, Societas puniri potest. La responsabilità da reato degli enti collettivi, Cedam, Padua, 2003.

, "La società punita: del come, del perchè, e del per cosa", en Rivista italiana di diritto e procedura penale, 2008.

Paliero, Carlo Enrico; Travi, Aldo, La sanzione administrativa, Giuffrè, Milán, 1988. 
Patalano, Vincenzo, "Profili problematici della corruzione internazionale", en Patalano, Vincenzo (Edit.), Nuove strategie per la lotta al crimine organizzato transnazionale, Giappichelli, Turín, 2003.

PaVARINI, Massimo, "Lo sguardo artificiale sul crimine organizzato", en GIOSTRA, Glauco; INSOleRA, Gaetano (Edit.), Lotta alla criminalità organizzata: gli strumenti normativi, Giuffrè, Milán, 1995.

PeCCIOLI, Annamaria, Unione Europea e criminalità transnazionale, Giappichelli, Turín, 2005.

Pérez CEPEDA, Ana Isabel, Globalización, tráfico internacional ilícito de personas y Derecho penal, Comares, Granada, 2004.

PicottI, Lorenzo; Fornasarl, Gabriele; VIGAnò, Francesco; Melchionda, Alessandro (Edits.), I reati associativi: paradigmi concettual e materiale probatorio, Cedam, Padua, 2005.

Pıcottı, Lorenzo, "La ratifica della Convenzione Cybercrime del Consiglio d'Europa", Diritto penale e processo 6, 2008.

PISANI, Mario, "Criminalità organizzata e cooperazione internazionale", Rivista italiana di diritto e procedura penale, 1998.

PistorelL, Luca, "La normativa antiriciclaggio introdotta dal d. Lg. 21 novembre 2007, № 231", Giurisprudenza di merito 10, 2008.

Plantamura, Vito, "Ecomafia, reati associativi e diritto penale dell'economia", Rivista trimestrale di diritto penale dell'economia, 2007.

Potetrı, Domenico, "Riflessioni in tema di confisca di cui alla legge 501/1994", Cassazione Penale, 1995.

Pulitanò, Domenico, "La responsabilità "da reato" degli enti: i criteri d'imputazione", Rivista italiana di diritto e procedura penale, 2002.

RESTA, Federica, "Cybercrime e cooperazione internazionale, nell'ultima legge della legislatura", Giurisprudenza di merito 9, 2008.

Rojas Aravena, Francisco, El crimen organizado internacional: una grave amenaza a la democracia en América Latina y el Caribe, Flacso, San José de Costa Rica, 2006.

Romano, Salvatore, Storia della mafia, Mondadori, Verona, 1966.

Romeo Casabona, Carlos María (Coord.), El cibercrimen: nuevos retos jurídico penales, nuevas respuestas político criminales, Comares, Granada, 2006.

Rosı, Elisabetta, "Il reato transnazionale", en Criminalità organizzata transnazionale e sistema penale italiano, Ipsoa, Milano, 2007.

Rosı, Elisabetta (Edit.), Criminalità organizzata transnazionale e sistema penale italiano, Ipsoa, Milán, 2007.

Rovito, Pier Luigi, "Mentalità emergenziale e crimine organizzato: profili storici", en MocciA, Sergio (Edit.). Criminalità organizzata e risposte ordinamentali, Edizioni Scientifiche Italiane, Nápoles, 1999. 
Roxın, Claus, "Problemas de autoría y participación en la criminalidad organizada", Traducción de Anarte, Enrique, Revista Penal, 2, 1998.

SACERDOtI, Giorgio, "La Convenzione OCSE del 1997 sulla lotta contro la corruzione dei pubblici ufficiali stranieri nella transazioni commerciali internazionali", Rivista italiana di diritto e procedura penale, 1998.

SALAZAR, Lorenzo, "Misure di contrasto alla criminalità organizzata elaborate dall'Unione Europea", en BAssıounl, Cherif M. (Edit.), La cooperazione internazionale per la prevenzione e la repressione della criminalitá organizata e del terrorismo, Giuffrè, Milán, 2005.

SCIAlOJA, Antonio, Le nuove norme antiriciclaggio. Criminalità organizzata e riciclaggio, Maggioli editore, Santarangelo di Romagna, 2006.

Sciumbata, Gabriele, I reati societari. 2a Edición, Giuffrè, Milán, 2008.

Scoletta, Marco, "Art. 24-ter, d. Igs. No 231/2001", en Corbetta, Stefano; Della Bella, Angela; GatTA, Gian Luigi (Edits.), Sistema penale e "sicurezza pubblica": le riforme del 2009, Ipsoa, Milán, 2009.

SelvagGI, Nicola, L'interesse dell'ente collettivo. Quale criterio di ascrizione della responsabilità da reato, Jovene Editore, Nápoles, 2006.

SFAMENI, Paolo, "La responsabilità delle persone giuridiche: fattispecie e disciplina dei modelli di organizzazione, gestione e controllo", en AlESSANDRI, Alberto (Edit.), Il nuovo diritto delle società, Ipsoa, Milán, 2002.

Silva SánCHEZ, Jesús María, La expansión del Derecho penal. Aspectos de política criminal en las sociedades postindustriales, $2^{\text {a }}$ Edición, Civitas, Madrid, 2001.

“La «intervención a través de organización» ¿una forma moderna de participación en el delito?", en DolCinI, Emilio; Paliero, Carlo Enrico (Edits.), Studi in onore di Giorgio Marinucci, T. II, Giuffrè, Milán, 2006.

Solís, Luis Guillermo; Rojas Aravena, Francisco (Edits.), Crimen organizado en América Latina y el Caribe, Catalonia, Santiago, 2008.

Sotıs, Carlo, "La novità in tema di diritto penale europeo", en BILANCIA, Paola; D’Amico, Marilisa (Edits.), La nuova Europa dopo il Tratatto di Lisbona, Giuffrè, Milán, 2009.

Spagnolo, Giuseppe, L'associazione di tipo mafioso, 5 a Edición, Cedam, Padua, 1997.

StIGEN, Jo, The relationship between the International Criminal Court and National Jurisdictions. The Principle of Complementarity, Nijhoff Publishers, Leiden-Boston, 2008.

SzCZARAnsky, Clara, "El Consejo de Defensa del Estado y el control de la criminalidad organizada y del lavado de dinero", en Politoff, Sergio; Matus, Jean Pierre (Coords.), Gran criminalidad organizada y tráfico ilícito de estupefacientes, ConoSur, Santiago, 2000. 
TERESI, Renato, Direzione nazionale e Direzioni distrettuali antimafia, Giuffrè, Milán, 1993.

TiedemanN, Klaus, "Die 'Bebußung' von Unternehmen nach dem 2. Gesetz zur Bekämpfung des Wirtschaftskriminalität", Neue Juristische Wochenschrift, 1988.

Tiedemann, Klaus, Lecciones de Derecho penal económico (Comunitario, español, alemán), PPU, Barcelona, 1993.

Tinebra, Giovanni; Centonze, Alessandro (Edits.), Il traffico internazionale di persone, Giuffrè, Milán, 2004.

TRIPODI, Andrea Francesco, "'Situazione organizzativa' e 'colpa in organizzazione': alcune riflessioni sulle nuove specificità del diritto penale dell'economia", Rivista trimestrale di diritto penale dell'economia 2004.

VV.AA., La responsabilità penale delle persone giuridiche in Diritto comunitario, Giuffrè, Milán, 1981.

VIGANÒ, Francesco, "Mafia e imprenditori: una decisione coraggiosa in tema di stato di necessità", Diritto penale e processo 10, 2004.

VIGNA, Piero Luigi, "Le nuove sfide della criminalità organizzata", en BECuCCI, Stefano; MAssarı, Monica, Mafie nostre, mafie loro. Criminalità organizzata italiana e straniera nel Centro-Nord, Edizioni di Comunità, Turín, 2001.

VISCONTI, Costantino, "Il concorso esterno nell'associazione mafiosa: profili dogmatici ed esigenze politico-criminali", Rivista italiana di diritto e procedura penale, 1995.

"Il concorso esterno tra aspetti di costituzionalità e prospettive di riforma legislativa", Diritto penale e processo 6, 1998.

Vizzardi, Matteo, "Art. 19", en Presutti, Adonella; Bernasconi, Alessandro; Fiorio, Carlo, La responsabilità degli enti. Commento articolo per articolo al D. Legisl. 8 giugno 2001 № 231, Cedam, Padua, 2008.

VULPIANI Domenico, "Criminalità organizzata ed informatica", en PARANO, Carola; CentOnZE, Alessandro (Edits.), L'attività di contrasto alla criminalità organizzata, Giuffrè, Milán, 2005.

Zaffaron, Eugenio, "Il crimine organizzato: una categoria fallita", en Moccia, Sergio (Edit.), Criminalità organizzata e risposte ordinamentali, Edizioni Scientifiche Italiane, Nápoles, 1999.

ZifFer, Patricia, El delito de asociación ilícita, Ad-Hoc, Buenos Aires, 2005.

ZúÑIGa Rodríguez, Laura, Criminalidad organizada y sistema de derecho penal. Contribución a la determinación del injusto penal de organización criminal, Comares, Granada, 2009. 